\title{
Tiny pollen grains: first evidence of Saururaceae from the Late Cretaceous of western North America
}

\author{
Fridgeir Grimsson ${ }^{\text {Corresp., }}{ }^{1}$, Guido W Grimm ${ }^{1,2}$, Reinhard Zetter ${ }^{1}$ \\ 1 Department of Palaeontology, University of Vienna, Wien, Austria \\ 2 Unaffiliated, None, Orléans, France \\ Corresponding Author: Fridgeir Grimsson \\ Email address: fridgeir.grimsson@univie.ac.at
}

Background. The Saururaceae, a very small family of Piperales comprising only six species in four genera, have a relatively scanty fossil record outside of Europe. The phylogenetic relationships of the four genera to each other are resolved, with the type genus Saururus occurring in both eastern North America and East Asia. No extant species occurs in western Eurasia. The most exceptional find so far has been an inflorescence with in-situ pollen, Saururus tuckerae S.Y.Sm. \& Stockey from Eocene of North America with strong affinities to extant species of Saururus. Recent dated trees suggest, however, an Eocene or younger crown age for the family.

Methods. Dispersed fossil pollen grains from the Campanian (82-81 Ma) of North America are compared to dispersed pollen grains from the Eocene strata containing $S$. tuckerae, the Miocene of Europe, and extant members of the family using combined LM and SEM imaging.

Results. The unambiguous fossil record of the Saururaceae is pushed back into the Campanian (82-81 $\mathrm{Ma}$ ). Comparison with re-investigated pollen from the Eocene of North America, the Miocene of Europe, and modern species of the family shows that pollen morphology in Saururaceae is highly conservative, and remained largely unchanged for the last 80 million years.

Discussion. Campanian pollen of Saururaceae precludes young (Eocene or younger) estimates for the Saururaceae root and crown age, but is in-line with maximum age scenarios. Saururus-type pollen appear to represent the primitive pollen morphology of the family. Often overlooked because of its small size, dispersed Saururaceae pollen may provide a unique opportunity to map the geographic history of a small but old group of Piperales, and should be searched for in Paleogene and Cretaceous sediment samples. 
1 Tiny pollen grains: first evidence of Saururaceae from the Late Cretaceous of

2

3

4

$5 \quad{ }^{1}$ University of Vienna, Department of Palaeontology, Vienna

$6 \quad{ }^{2}$ Unaffiliated, Orléans, France

7

8 Corresponding author:

9 Friðgeir Grímsson

10 Althanstraße 14, UZA II, 1090 Vienna

11 Email: fridgeir.grimsson@univie.ac.at

12 western North America

\author{
Friðgeir Grímsson ${ }^{1}$, Guido W. Grimm ${ }^{1,2}$, Reinhard Zetter ${ }^{1}$
}


14 Background. The Saururaceae, a very small family of Piperales comprising only six species in 15 four genera, have a relatively scanty fossil record outside of Europe. The phylogenetic relationships of the four genera to each other are resolved, with the type genus Saururus

17 occurring in both eastern North America and East Asia. No extant species occurs in western 18 Eurasia. The most exceptional find so far has been an inflorescence with in-situ pollen, Saururus tuckerae S.Y.Sm. \& Stockey from Eocene of North America with strong affinities to extant 20 species of Saururus. Recent dated trees suggest, however, an Eocene or younger crown age for 21 the family.

22 Methods. Dispersed fossil pollen grains from the Campanian (82-81 Ma) of North America are 23 compared to dispersed pollen grains from the Eocene strata containing $S$. tuckerae, the Miocene 24 of Europe, and extant members of the family using combined LM and SEM imaging.

25 Results. The unambiguous fossil record of the Saururaceae is pushed back into the Campanian 26 (82-81 Ma). Comparison with re-investigated pollen from the Eocene of North America, the 27 Miocene of Europe, and modern species of the family shows that pollen morphology in 28 Saururaceae is highly conservative, and remained largely unchanged for the last 80 million years. 29 Discussion. Campanian pollen of Saururaceae precludes young (Eocene or younger) estimates 30 for the Saururaceae root and crown age, but is in-line with maximum age scenarios. Saururus31 type pollen appear to represent the primitive pollen morphology of the family. Often overlooked 32 because of its small size, dispersed Saururaceae pollen may provide a unique opportunity to map 33 the geographic history of a small but old group of Piperales, and should be searched for in 34 Paleogene and Cretaceous sediment samples. 


\section{Introduction}

Smith \& Stockey (2007a) described inflorescences and flowers with in-situ pollen from the Eocene of North America that they assigned then to the modern genus Saururus $(S$. tuckerae S.Y.Sm. \& Stockey). Saururaceae are a very small magnoliid family included in the Piperales (APG III 2009), with six currently accepted species in four genera. In addition to Saururus cernuus L. and S. chinensis (Lour.) Baill., these are: Anemopsis californica Hook. \& Arn., Gymnotheca chinensis Decne., Gymnotheca involucrata Pei, and Houttuynia cordata Thunb. An interesting pattern is the modern disjunct distribution of both of the two mutually monophyletic lineages in the Saururaceae (Anemopsis + Houttuynia vs. Gymnotheca + Saururus; Massoni, Forest \& Sauquet 2014) in North America and South/East Asia, suggesting that the family probably had a much wider distribution in the past (Table 1). The fossil record of Saururaceae is scanty (Table 2). Most of the fossils are fruits/seeds from the Eocene to Pliocene of western Eurasia and have been assigned to Saururus (S. bilobatus [Nikitin] Mai). In addition, Mai (1999) described fruits/seeds from the lower Miocene of Germany as Houttuynia bavarica Mai. The oldest fossil record so far is fossil wood from the Upper Cretaceous (no detailed stratigraphic information available) of Hokkaido described as Saururopsis niponensis Stopes \& Fujii (1910, p. 58ff); the authors discuss carefully the affinity of the fossil and suggest that it could represent an ancestral member of the Saururaceae combining wood features typical for either Saururus or Houttuynia. The Eocene Saururus tuckerae (Smith \& Stockey 2007a) is so far the only fossil reported from North America. Though scanty, the fossil record confirms that Saururaceae were widespread by the Paleogene. The fossil record is also in line with the latest molecular dating estimates of a magnoliid dataset. According to the dating analyses of Massoni, Couvreur \& Sauquet (2015b), the divergence between the two clades of the Saururaceae (Anemopsis + Houttuynia vs. Gymnotheca + Saururus) was established at the latest by the Eocene ( $>45 \mathrm{Ma})$, and the modern genera (and disjunctions) by the late Miocene (> $10 \mathrm{Ma}$; Table 3). Two nodes in the phylogenetic neighbourhood of the Saururaceae were constrained using fossil age priors: the Saururus ( $\geq 44.3 \mathrm{Ma}$; 'safe' minimum constraint with reference to S. tuckerae) and Winteraceae root ages (= Canellales crown age; $\geq 126$ Ma; Massoni, Doyle \& Sauquet 2015). Here, we document fossil pollen from the middle Upper Cretaceous Eagle Formation (Fm) of Wyoming, western North America, that is very similar to those of extant Saururus and nearly identical to 
68 that of pollen recovered in situ from Saururus tuckerae from the Eocene of British Columbia.

69 Our findings are discussed in the context of newly documented dispersed Saururus pollen from

70 the Eocene of British Columbia and Miocene of Central Europe (Austria), and the recent dating

71 estimates for the family.

72 Material \& Methods

73 Palaeopalynological samples

74 The sedimentary rock samples containing the dispersed fossil Saururus pollen grains 75 presented in this study originate from three different localities:

1) the Elk basin, Wyoming, north-western United States $\left(44^{\circ} 59^{\prime} \mathrm{N} / 108^{\circ} 52^{\prime} \mathrm{W}\right)$; the sediment sample comes from the Campanian Eagle Fm and was provided by the late Leo Hickey (1940-2013). For detailed chronometric (absolute dating of the overlying benthonite; Hicks 1993) and stratigraphic information and palaeobotanical background of this locality see Hicks (1993), Van Boskirk (1998), Manchester, Grímsson \& Zetter (2015), and Grímsson et al. (2016a).

2) an outcrop of the Princeton Chert beds, Similkameen River, British Columbia, Canada $\left(49^{\circ} 22^{\prime} \mathrm{N}, 120^{\circ} 32^{\prime} \mathrm{W}\right)$. The Princeton Chert beds are part of the middle Eocene Allenby Fm and comprise at least 49 rhythmically bedded cherts, interbedded by carbonaceous layers (e.g. Read 2000; Smith \& Stockey 2007a; Mustoe 2011). The sample originates from chert-bed 43 (uppermost quarter of the Princeton Chert unit) and was provided by Ruth Stockey. Overlaying and underlying beds have been chronometrically dated. According to Moss, Greenwood \& Archibald (2005, fig. 2) an age of ca 48 Ma can be assumed for this part of the formation.

3) An open cast clay pit, Stoob-Warasdorf-Forest, Burgenland, Austria. No chronometric dates are available; bio- and lithostratigraphy indicate a Miocene age (Klaus 1982).

\section{Sample preparation and the single grain method}

93 The sediment samples were processed and pollen grains extracted according to the protocol 94 outlined in Grímsson, Denk \& Zetter (2008). The fossil Saururaceae pollen grains were 
95 investigated both by light microscopy (LM) and scanning electron microscopy (SEM) using the

96 single grain method described in Zetter (1989).

\section{Pollen descriptions and comparison to extant material}

The description of the fossil pollen grains includes diagnostic features observed both in LM and SEM. Some grains were deliberately broken to expose the pollen wall to measure the exine and nexine thickness using SEM. TEM measurements for Saururus tuckerae are based on Smith \& Stockey (2007a, fig. 29) and Smith \& Stockey (2007b, fig.12B). Pollen terminology follows Punt et al. (2007) and Hesse et al. (2009). The fossil pollen grains were compared to all previously published Saururaceae pollen that have been documented using LM and SEM (Xi 1980; Takahashi 1986; Pontieri \& Sage 1999; Sampson 2000; Furness, Rudall \& Sampson 2002; Smith \& Stockey 2007a; Smith \& Stockey 2007b; Lu et al. 2015). Additional material (Table S1) from the herbarium of the University of Vienna (WU) was used for a more detailed comparison (pollen figured in File S1).

\section{Preparation of extant material}

A single or a few anthers from each sample were placed into drops of acetolysis liquid (nine to one mix of $99 \%$ acetic anhydride and $95-97 \%$ sulphuric acid) on microscopic glass slides to soften up the anthers, release the pollen grains from anthers, dissolve extra organic material on pollen grain surfaces, rehydrate pollen grains and release their cell contents, and finally, to stain the grains for LM photography. The slides were heated over a candle flame to speed up the process. Pollen grains were then transferred into fresh drops of glycerine and photographed under LM and then transferred to SEM stubs using a micromanipulator and washed with drops of absolute ethanol. Stubs were sputter-coated with gold and the pollen grains photographed under a JEOL 6400 SEM.

\section{Conservation of fossil and extant pollen material}

SEM stubs produced for this study are stored in the collection of the Department of Palaeontology, University of Vienna, Austria, under accession numbers IPUW 7513/101-130. 


\section{Systematic palaeobotany}

123 Nomenclatural note. We believe that a fossil name should reflect the biological affinity 124 indicated by the morphology of the fossil. Taking together all evidence, our Cretaceous pollen 125 grains either represent an ancestral lineage within the Saururaceae that shared the primitive 126 pollen morphology of extant and Cenozoic Saururus (hypothesis 1 below) or an early member of 127 the Saururus-lineage (hypothesis 2). A name best reflecting hypothesis 1 would be to erect a new 128 genus named e.g. "Protosaururus". However, this is impractical. The genus diagnosis could only 129 be based on the Cretaceous pollen grains, and would be non-exclusive regarding pollen of the 130 actual Saururus-lineage. If the currently prevalent cladistic-phylogenetic nomenclature that only 131 accepts taxa that have a (putative) inclusive common origin should be followed, i.e. are 132 'monophyletic' in a strict sense (Hennig 1950; Hennig \& Schlee 1978), termed also 133 'holophyletic' by (Ashlock 1971), the Cretaceous fossils would need to be addressed as

134 “Saururaceae gen. et sp. indet." (hypothesis 1) or Saururus (hypothesis 2). For consistency, our 135 and future Saururus-type pollen grains would need to be named based on the currently accepted 136 divergence ages for the Saururaceae (Fig. 1). An alternative solution that serves the requirements 137 of the Botanical Code for unambiguous diagnoses is to follow the concept of "evolutionary 138 classification” (e.g. Mayr \& Bock 2002; Hörandl 2006; Hörandl 2007), which allows naming 139 also 'paraphyletic' groups to avoid that groups of directly related organisms with a non-inclusive 140 common origin and similar or identical morphology are addressed by different names (Fig. 1). In 141 this case, one does not need to decide which hypothesis (paraphyletic Saururus pollen vs. 142 holophyletic Saururus) applies when naming the pollen; and all Saururus-type pollen can be 143 addressed as Saururus spp.

\section{Saururus aquilae sp. nov. (Figures 2-4A-G)}

145 Holotype. IPUW 7513/101 (Figs 2A, 4E,F)

146 Paratypes. IPUW 7513/102-111 (Figs 2B-H, 3, 4A-D,G,H)

147 Type locality. Elk Basin, Wyoming, United States.

148 Stratigraphy and age. Lettered Sands Member, Upper Eagle beds, Eagle Fm, Upper 149 Cretaceous (Campanian); 82-81 Ma (Hicks 1993; Van Boskirk 1998).

150 Species diagnosis. Sculpture perforate, psilate to granulate; proximal face with about five 151 perforations per $\mu \mathrm{m}^{2}$; perforations can have lobate outlines and up to six free-standing and/or 
152 protruding columellae; exine $\leq 400 \mathrm{~nm}$ and nexine $<200 \mathrm{~nm}$ thick. All other pollen features that can be observed under LM and SEM as in the two modern species of the genus.

154 Description. Pollen, monad, shape oblate, form boat-like to globose, outline elliptic in 155 equatorial and polar view; size very small, polar axis 3-5 $\mu \mathrm{m}$ long in SEM, equatorial diameter 156 6-11 $\mu \mathrm{m}$ in SEM; sulcate, sulcus with rounded ends (SEM); tectate; exine c. $400 \mathrm{~nm}$ thick, 157 nexine c. $140 \mathrm{~nm}$ thick, nexine thinner than sexine (SEM); sculpture psilate in LM, perforate, 158 psilate to granulate in SEM, 20-25 perforations per $4 \mu \mathrm{m}^{2}$, perforations tiny to small, circular, 159 elliptic, irregular, irregular elongated to lobate in outline, perforations fewer and smaller on distal 160 polar face (SEM), perforations are characterized by 1-6 free-standing and/or protruding 161 columellae, free-standing columellae at periphery of perforations or sometimes filling them 162 completely (SEM); sulcus membrane microechinate, microechini mostly with blunt apex, microechini densely packed to segregated (SEM).

164 Remarks. The description is based on c. 50 individual dispersed pollen grains studied both in

165 LM and SEM. The Cretaceous S. aquilae pollen grains are very similar to or indistinguishable from the Eocene pollen of $S$. tuckerae that has been found both in situ in inflorescences/flowers (Smith \& Stockey 2007a) and dispersed in the same sediments (Zetter 2006; this study). The only differences are found in the sculpture of the sulcus membrane: in some grains of $S$. aquila, the microechini can be densely packed (Fig. 2A,C; Fig. 4C,E,F), whereas they are widely spaced in S. tuckerae and the two modern species of Saururus (Table 4; Supplementary File S1). The pollen grains of both taxa are even smaller than pollen of Miocene (S. stoobensis sp. nov., below) and extant Saururaceae except for Gymnotheca. They show the same basic SEM sculpture ranging from perforate, psilate to granulate; a variation also seen in the Miocene pollen but not to

174 the same degree in extant members of the Saururaceae. The main diagnostic feature 175 distinguishing $S$. aquilae from the Cretaceous and $S$. tuckerae from the Miocene and modern 176 species of the genus is their high density of perforations ( $\geq 20$ per $4 \mu \mathrm{m}^{2}$ on the proximal pollen

177 face compared to $\leq 10$ per $4 \mu \mathrm{m}^{2}$ in S. stoobensis, S. cernuus, and S. chinensis). Furthermore, 178 they both show up to six free-standing/protruding columellae at the periphery of perforations compared to a maximum of four in extant species of the Saururaceae. Occasionally lobate 180 perforations in addition to the more common circular, elliptical and irregular perforations 181 represent a feature seen only in the fossil Saururus pollen and the extant S. chinensis. Exine and 182 nexine in both taxa are slightly but consistently thinner than in extant Sauruaceae. The $S$. aquilae 
183 pollen grains differ from those of Gymnotheca, Houttuynia, and Anemopsis. Pollen grains of

184 Gymnotheca differ from S. aquilae and fossil and extant Saururus by their prominently striate 185 and nanoechinate SEM sculpture; their perforations are without free-standing/protruding 186 columellae. Houttuynia pollen grains are considerably larger than pollen of S. aquilae, and are 187 unique within Saururaceae in having a microverrucate sulcus membrane; their exine is much 188 thicker than in S. aquilae. Anemopsis pollen grains have sulcus membranes that are echinate to 189 rugulate, a feature not seen in any other fossil or extant Saururaceae.

190 Derivation of name. The species is named after the Eagle (lat. aquila) Fm.

Saururus tuckerae S. Y.Sm. \& Stockey (Figures 4H, 5, 6, 7A-D)

192 2007a Saururus tuckerae - Smith \& Stockey, figs 21, 22, 26, 29. 2007b Saururus tuckerae - Smith \& Stockey, figs 11A-E, 12A-C.

Description. Pollen, monad, shape oblate, form boat-like, outline elliptic in equatorial and polar view; size very small, polar axis 3-5 $\mu \mathrm{m}$ long in SEM, equatorial diameter $6-11 \mu \mathrm{m}$ in SEM; sulcate, sulci with rounded ends (SEM); tectate; exine c. $370 \mathrm{~nm}$ thick, nexine c. $150 \mathrm{~nm}$ thick, nexine thinner than sexine (TEM); sculpture psilate in LM, perforate, psilate to granulate in SEM, 23-26 perforations per $4 \mu \mathrm{m}^{2}$, perforations tiny to small, circular, elliptic, irregular, (SEM), perforations are characterized by 2-6 freestanding and/or protruding columellae, freestanding-columellae at periphery of perforations or sometimes filling it completely (SEM); sulcus membrane microechinate, microechini mostly with blunt apex, microechini segregated 205 (SEM).

Remarks. The description is based on c. 200 individual dispersed pollen grains studied under For additional remarks see remarks for Saururus aquilae.

Saururus stoobensis sp. nov. (Figure 7E-G)

2102007 “Saururipollis sp.” (nomen nudum) - Ferguson et al., Pl. 2, figs 1-4 (same grain).

211 Holotype. IPUW 7513/124 (Fig. 7E-G). 
212 Type locality. Opencast clay pit, Stoob-Warasdorf-Forest, Burgenland, Austria.

213 Age. Miocene (Pannonian ?; = Tortonian to Messinian, c. 12-6 Ma; Klaus 1982)

214 Species diagnosis. Sculpture perforate, psilate to granulate; perforations occasionally with 215 lobate outlines. All other pollen features (size, form, sculpture of sulcus membrane, number of 216 perforations per $\mu \mathrm{m}^{2}$ ) that can be observed under LM and SEM as in the two modern species of 217 the genus.

218 Description. Pollen, monad, shape oblate, form boat-like, outline elliptic in equatorial view; 219 size very small, polar axis 4-5 $\mu \mathrm{m}$ long in SEM, equatorial diameter 10-11 $\mu \mathrm{m}$ in SEM; sulcate, 220 sulci with rounded ends (SEM); tectate; sculpture psilate in LM, perforate, psilate to granulate in $221 \mathrm{SEM}, 7-10$ perforations per $4 \mu \mathrm{m}^{2}$, perforations tiny to small, circular, elliptic or irregular in 222 outline, perforations fewer and smaller on distal polar face (SEM), perforations are characterized 223 by $2-4$ freestanding and/or protruding columellae, freestanding columellae at periphery of 224 perforations (SEM).

225 Remarks. The Miocene Saururus stoobensis pollen is more similar to the pollen of extant 226 Saururus (Table 4; Supplementary File S1) than the Cretaceous and Eocene Saururus pollen. It 227 is of similar size, has the same density of perforations and the same number of free-standing 228 columellae. It slightly differs from both modern species in the variation of the sculpture seen in 229 SEM, and the occasional occurrence of perforations with lobate outline, which can be found in $S$. 230 chinensis and the older fossil taxa, but has so far not been observed in S. cernuus or other 231 Saururaceae genera.

\section{Discussion}

234

235

236

237

238

239

240

\section{Fossil records of Saururaceae on the backdrop of latest molecular age estimates (Massoni, Couvreur \& Sauquet 2015b)}

Until now the fossil record of Saururaceae has been confined to the Cenozoic except for wood remains from the Late Cretaceous of Japan described a century ago (Stopes \& Fujii 1910). Most specimens have been linked to the extant genus Saururus (Table 2). Figure 8 shows the fossil record in comparison to the magnoliid subtree that includes the Saururaceae, extracted from the dated trees provided by Massoni, Couvreur \& Sauquet (2015a). The fossil pollen S. aquilae 
241 described here from the middle Late Cretaceous (Campanian) of Wyoming, conflicts with the 242 youngest dating estimates, which infer a Late Cretaceous to Paleocene root age for the 243 Saururaceae. Under the oldest age scenario (Massoni, Couvreur \& Sauquet 2015a, 2015b), the 244 Wyoming pollen falls (time-wise) in the (arithmetic) middle between the Saururaceae root and 245 crown divergence ages. On the backdrop of the dating estimates, $S$. aquilae could be the pollen 246 produced by a potential precursor of all extant Saururaceae genera (hypothesis 1). Hypothesis 1 247 would fit also with the interpretation of the Cretaceous fossil wood described as Saururopsis 248 nipponensis from Japan (Stopes \& Fujii 1910). Although being more similar to wood of 249 Saururus, Stopes and Fujii state that some features are reminiscent of Houttuynia, which belongs 250 to the second lineage of extant Saururaceae (e.g. Massoni, Forest \& Sauquet 2014), and 251 discussed the possibility that the wood comes from an ancestral member of the family. On the 252 other hand, the tip ages are poorly constrained (likely too young) using Massoni et al.'s (2015b) 253 dataset, who focussed on (much) deeper nodes. Hence, S. aquilae could represent an early 254 member of the Saururus-lineage (hypothesis 2). Notably, the age of S. aquilae is close to the 255 lower boundary of the highest posterior density (HPD) intervals for the older age scenarios (Fig. 256 8; Massoni, Couvreur \& Sauquet 2015a). Being interested in large-scale magnoliid processes, 257 Massoni, Couvreur \& Sauquet (2015b) did not use any age priors from within the Piperales 258 subtree (Massoni, Doyle \& Sauquet 2015) and relied on relatively slow-evolving gene regions. It 259 is a common observation that divergence ages towards the leaves of a tree tend to be (severely) 260 underestimated in studies using large datasets when compared to focused studies that rely on 261 ingroup constraints. Typically, the latter are in better agreement with the fossil record, as e.g. in 262 the case of the Fagaceae (Hubert et al. 2014; Grímsson et al. 2015, 2016a; Renner et al. 2016). A 263 similar observation can be made in the sister group of the Piperales, the Canellales. Figure 8 also 264 shows the oldest records of the Winteraceae, which are much older than the age estimates by 265 Massoni, Couvreur \& Sauquet (2015a, 2015b). Studies focusing on either Canellaceae (Müller et 266 al. 2015) or Winteraceae (Marquínez et al. 2009; Thomas et al. 2014), using different sets of age 267 priors including Canellaceae and Winteraceae crown group fossils, obtained (much) older ages 268 than the oldest age scenario (angiosperm root fixed to max. $200 \mathrm{Ma}$ ) in the set of analyses 269 performed by Massoni, Couvreur \& Sauquet (2015b). Differences range from at least 13 Ma for 270 the Canellaceae and Winteraceae roots to more than $40 \mathrm{Ma}$ for close-to-tips nodes. 
Based on pollen morphology, neither hypotheses can be rejected. Saururus aquilae is 272 essentially indistinguishable from pollen linked to the c. $30 \mathrm{Ma}$ younger $S$. tuckerae, and all 273 modern Saururaceae pollen types ( $\geq 35$ Ma younger) differ only in a few characters (Table 4; 274 File S1). The differences are often expressed as a range of variability (such as outlines of 275 perforations or sculpture of the pollen surface). This demonstrates that pollen morphology is a 276 very conservative trait in the lineage, and provides an argument for hypothesis 2 that $S$. aquilae

277

278

279

280

281

282

283

284

285

286

287

288

289

290

291

292

293

294

295

296

297

298

299

300 was produced by an early member of the genus Saururus. On the other hand, the extant six species are clearly only the last survivors of a once more widespread group (Table 1), and may be unrepresentative regarding the actual variation in each generic lineage and the family over time. The pollen of Saururus may simply be primitive within the family. Ancestral members of the Saururaceae including precursors of all modern genera may have produced essentially the same pollen (hypothesis 1), whereas pollen morphologies of the extant species of the other genera are more derived (Fig. 9).

\section{The importance of an in-depth analysis of the dispersed pollen record}

Pollen of Saururaceae is very small (literally, using the size categories of Hesse et al. 2009), and has probably been overlooked or ignored in many palynological studies (see also Smith \& Stockey 2007b. A major problem that directly affects the recovery of Saururaceae pollen is that the standard (LM) paleopalynological approach is to sieve the sediment with $10 \mu \mathrm{m}$ sieves, which means that most if not all Saururaceae pollen will be lost. Hence, the lack of Saururaceae pollen all over the Northern Hemisphere may be in part a sieving artefact. The single grain method using a combination of LM and SEM imaging (e.g. Zetter 1989) is a time-consuming approach, but as demonstrated here the information obtained can be highly beneficial to other botanical disciplines such as (i) molecular dating by providing new/alternative age priors (e.g. Hubert et al. 2014) and (ii) the study of historical biogeography by providing actual evidence for the occurrence of a certain lineage at a certain time in a certain place (e.g. Denk, Grímsson \& Zetter 2010; Grímsson, Zetter \& Hofmann 2011; Grímsson et al. 2015, 2016a). A main advantage of pollen for assessing past distribution is its high evolutionary conservatism across long periods of time. For the Saururaceae the data presented here and the in-situ grains showed by Smith \& Stockey (2007a) prove that the main characteristics of Saururaceae pollen (Smith \& Stockey 2007b; this study) have remained essentially unchanged for over $80 \mathrm{Ma}$. This is not an 
301 exception; Fagus, castaneoid and cornalean pollen can be traced back at least to the Danian of

302 western Greenland (Manchester, Grímsson \& Zetter 2015; Grímsson et al. 2016a), and is part of

303 a very rich pollen flora covering at least 32 families of angiosperms (Grímsson et al. 2016b);

304 castanoid pollen of the sister clade of Fagus (all other Fagaceae) has been found in the same

305 sample as the Saururaceae pollen described here (Grímsson et al. 2016a) in addition to asteroid

306 families such as the Araliaceae and Oleaceae (Manchester, Grímsson \& Zetter 2015). Friis,

307 Crane \& Pedersen (2011) consistently and repeatedly express their concern regarding the

308 affiliation of many (macro)fossils of the Cretaceous fossil record with angiosperm taxa. For

309 instance, regarding Saururopsis niponensis, the Late Cretaceous wood from Hokkaido (Stopes \&

310 Fujii 1910), they state that "the relationships of this material require further study" (Friis, Crane

$311 \&$ Pedersen 2011, p. 248). We agree; and advocate the use of comprehensive, in-depth studies of

312 the dispersed and in-situ pollen record using the combination of LM and SEM imaging on the

313 same, single grain to fill the many gaps obscuring the origin of the angiosperms, their Cretaceous

314 diversity and spatial distribution, and the roots of the modern lineages and their precursors (e.g.

315 Doyle, Hotton \& Ward 1990; Takahashi 1997; Zetter, Hesse \& Huber 2002; Hofmann \& Zetter

316 2007, 2010; Grímsson, Zetter \& Hofmann 2011; Hofmann et al. 2011; Grímsson et al. 2014,

317 2016a; Mendes et al. 2014; Manchester, Grímsson \& Zetter 2015)

318

319

320

321

322

323

324

325

326

327

328

329

330

331

332

\section{Acknowledgements}

Thanks go to Jim Doyle who reviewed an earlier version of this manuscript, and Lanny Fisk and a second peer for reviewing the manuscript submitted to PeerJ.

\section{References}

APG III. 2009. An update of the Angiosperm Phylogeny Group classification for the orders and families of flowering plants: APG III. Botanical Journal of the Linnéan Society 161:105121.

Ashlock PD. 1971. Monophyly and associated terms. Systematic Zoology 20:63-69.

Denk T, Grímsson F, Zetter R. 2010. Episodic migration of oaks to Iceland: Evidence for a North Atlantic "land bridge" in the latest Miocene. American Journal of Botany 97:276-287.

Dorofeyev PI. 1963. The Tertiary floras of Western Siberia. Moskva, Leningrad: Izd-vo Akademii nauk SSSR.

Doyle JA, Hotton CL, Ward JV. 1990. Early Cretaceous tetrads, zonasulcate pollen, and Winteraceae. I. Taxonomy, morphology, and ultrastructure. American Journal of Botany 77:1544-1557. 
333 Ferguson DK, Zetter R, Paudayal KN. 2007. The need for SEM in Palaeopalynology. Comptes

334

335

336

337

338

339

340

341

342

343

344

345

346

347

348

349

350

351

352

353

354

355

356

357

358

359

360

361

362

363

364

365

366

367

368

369

370

371

372

373

374

375

376

377

378
Friis EM. 1985. Angiosperm fruits and seeds from the Middle Miocene of Jutland (Denmark). Det Kongelige Danske Videnskabernes Selskab Biologiske Skrifter 24:1-165.

Friis EM, Crane PR, Pedersen KR. 2011. Early Flowers and Angiosperm Evolution. Cambridge, U.K.: Cambridge University Press.

Furness CA, Rudall PJ, Sampson FB. 2002. Evolution of microsporogenesis in angiosperms. International Journal of Plant Sciences 163:235-260.

Grímsson F, Denk T, Zetter R. 2008. Pollen, fruits, and leaves of Tetracentron (Trochodendraceae) from the Cainozoic of Iceland and western North America and their palaeobiogeographic implications. Grana 47:1-14.

Grímsson F, Grimm GW, Zetter R, Denk T. 2016a. Cretaceous and Paleogene Fagaceae from North America and Greenland: evidence for a Late Cretaceous split between Fagus and the remaining Fagaceae. Acta Palaeobotanica 56:000-000.

Grímsson F, Pedersen GK, Grimm GW, Zetter R. 2016b. A revised stratigraphy for the Paleocene Agatdalen flora (Nuussuaq Peninsula, western Greenland): correlating fossiliferous outcrops, macrofossils, and palynological samples from phosphoritic nodules. Acta Palaeobotanica 56:000-000.

Grímsson F, Zetter R, Grimm GW, Krarup Pedersen G, Pedersen AK, Denk T. 2015. Fagaceae pollen from the early Cenozoic of West Greenland: revisiting Engler's and Chaney's ArctoTertiary hypotheses. Plant Systematics and Evolution 301:809-832.

Grímsson F, Zetter R, Halbritter H, Grimm GW. 2014. Aponogeton pollen from the Cretaceous and Paleogene of North America and West Greenland: Implications for the origin and palaeobiogeography of the genus. Review of Palaeobotany and Palynology 200:161-187.

Grímsson F, Zetter R, Hofmann C-C. 2011. Lythrum and Peplis from the Late Cretaceous and Cenozoic of North America and Eurasia: New evidence suggesting early diversification within the Lythraceae. American Journal of Botany 98:1801-1815.

Haeckel E. 1866. Generelle Morphologie der Organismen. Berlin: Georg Reiner.

Hennig W. 1950. Grundzüge einer Theorie der phylogenetischen Systematik. Berlin: Dt. Zentralverlag.

Hennig W, Schlee D. 1978. Abriß der phylogenetischen Systematik. Stuttgarter Beiträge zur Naturkunde, Ser A 319:1-11.

Hesse M, Halbritter H, Zetter R, Weber M, Buchner R, Frosch-Radivo A, Ulrich S. 2009. Pollen terminology - An illustrated handbook. Wien, New York: Springer.

Hicks JF. 1993. Chrono-stratigraphic analysis of the foreland basin sediments of the latest Cretaceous, Western Interior, U.S.A.Ph.D. Yale University.

Hofmann C-C, Spicer RA, Ahlberg A, Herman AB. 2011. Scanning electron microscopy investigation of monads and tetrads of basal core eudicots from the Upper Cretaceous Vilui Basin, Siberia: Evidence for reticulate evolution. Review of Palaeobotany and Palynology 167:196-211.

Hofmann C-C, Zetter R. 2007. Upper Cretaceous pollen flora from the Vilui Basin, Siberia: Circumpolar and endemic Aquilapollenites, Manicorpus, and Azonia. Grana 46:227-249.

Hofmann C-C, Zetter R. 2010. Upper Cretaceous sulcate pollen from the Timerdyakh Formation, Vilui Basin (Siberia). Grana 49:170-193.

Hörandl E. 2006. Paraphyletic versus monophyletic taxa - evolutionary versus cladistic classifications. Taxon 55:564-570. 
379 Hörandl E. 2007. Neglecting evolution is bad taxonomy. Taxon 56:1-5.

380 Hubert F, Grimm GW, Jousselin E, Berry V, Franc A, Kremer A. 2014. Multiple nuclear genes

381

382

383

384

385

386

387

388

389

390

391

392

393

394

395

396

397

398

399

400

401

402

403

404

405

406

407

408

409

410

411

412

413

414

415

416

417

418

419

420

421

422

423

424 stabilize the phylogenetic backbone of the genus Quercus. Systematics and Biodiversity 12:405-423.

Klaus W. 1982. Die Kanarenkiefer (Pinus canariensis Smith ssp. prisca n. ssp.) und weitere Kiefernreste aus dem Jung-Tertiär von Stoob im Burgenland (Austria). In: Biologisches Forschungsinstitut Burgenland, editor. BFB-Bericht: Biologische Station Neusiedlersee. $p$ (11 pp.).

Łańcucka-Srodoniowa R. 1979. Macroscopic plant remains from the freshwater Miocene of the Nowy Sącz Basin (West Carpathians, Poland). Acta Palaeobotanica 20:3-117.

Lesiak MA. 1994. Plant macrofossils from the middle Miocene of Lipnica Mała (Orawa-Nowy Targ Basin, Poland). Acta Palaeobotanica 34:27-81.

Lu L, Wortley AH, Li D-z, Wang H, Blackmore S. 2015. Evolution of angiosperm pollen. 2. The basal angiosperms. Annals of the Missouri Botanical Garden 100:227-269.

Mai DH. 1965. Eine pliozäne Flora von Kranichfeld in Thüringen. Abhandlungen des Zentralen Geologischen Instituts 1:37-64.

Mai DH. 1967. Die Florenzonen, der Florenwechsel und die Vorstellungen über den Klimaablauf im Jungtertiär der Deutschen Demokratischen Republik. Abhandlungen des Zentralen Geologischen Instituts 10:55-82.

Mai DH. 1995. Tertiäre Vegetationsgeschichte Europas. Jena, Stuttgart, New York: Gustav Fischer Verlag.

Mai DH. 1999. Die untermiozänen Floren aus der Spremberger Folge und dem 2. Flözhorizont in der Lausitz Teil II: Polycarpicae und Apetalae. Palaeontographica Abteilung B 251:1-70.

Mai DH, Walther H. 1978. Die Floren der Haselbacher Serie im Weißelster-Becken (Bezirk Leipzig, DDR). Abhandlungen des Staatlichen Museums für Mineralogie und Geologie zu Dresden 28:1-200.

Mai DH, Walther H. 1985. Die obereozänen Floren des Weißelster-Beckens und seiner Randgebiete. Abhandlungen des Staatlichen Museums für Mineralogie und Geologie zu Dresden 33:5-260.

Manchester SR, Grímsson F, Zetter R. 2015. Assessing the fossil record of asterids in the context of our current phylogenetic framework. Annals of the Missouri Botanical Garden 100:329363.

Marquínez X, Lohmann LG, Salatino MLF, Salatino A, González F. 2009. Generic relationships and dating lineages in Winteraceae based on nuclear (ITS) and plastid (rpS16 and psbA$\operatorname{trnH})$ sequence data. Molecular Phylogenetics and Evolution 53:435-449.

Massoni J, Couvreur TLP, Sauquet H. 2015a. Data from: Five major shifts of diversification through the long evolutionary history of Magnoliidae (angiosperms). Dryad Digital Repository. http://dx.doi.org/10.5061/dryad.ct231

Massoni J, Couvreur TLP, Sauquet H. 2015b. Five major shifts of diversification through the long evolutionary history of Magnoliidae (angiosperms). BMC Evolutionary Biology 15:49.

Massoni J, Doyle J, Sauquet H. 2015. Fossil calibration of Magnoliidae, an ancient lineage of angiosperms. Palaeontologia Electronica 18.1.2FC:1-25.

Massoni J, Forest F, Sauquet H. 2014. Increased sampling of both genes and taxa improves resolution of phylogenetic relationships within Magnoliidae, a large and early-diverging clade of angiosperms. Molecular Phylogenetics and Evolution 70:84-93. 
425

426

427

428

429

430

431

432

433

434

435

436

437

438

439

440

441

442

443

444

445

446

447

448

449

450

451

452

453

454

455

456

457

458

459

460

461

462

463

464

465

466

467

468

469

470

Mayr E, Bock WJ. 2002. Classifications and other ordering systems. Journal of Zoological Systematics and Evolutionary Research 40:169-194.

Mendes MM, Dinis J, Pais J, Friis EM. 2014. Vegetational composition of the Early Cretaceous Chicalhão flora (Lusitanian Basin, western Portugal) based on palynological and mesofossil assemblages. Review of Palaeobotany and Palynology 200:65-81.

Moss PT, Greenwood DR, Archibald SB. 2005. Regional and local vegetation community dynamics of the Eocene Okanagan Highlands (British Columbia - Washington State) from palynology. Canadian Journal of Earth Sciences 42:187-204.

Müller S, Salomo K, Salazar J, Naumann J, Jaramillo MA, Neinhuis C, Feild TS, Wanke S. 2015. Intercontinental long-distance dispersal of Canellaceae from the New to the Old World revealed by a nuclear single copy gene and chloroplast loci. Molecular Phylogenetics and Evolution 84:205-219.

Mustoe GE. 2011. Cyclic sedimentation in the Eocene Allenby Formation of south-central British Columbia and the origin of the Princeton Chert fossil beds. Canadian Journal of Earth Sciences 48:25-43.

Nikitin PA. 1965. The Akvitian seed flora of Lagerny Sad. Tomsk: Tomsk State University.

Pontieri V, Sage TL. 1999. Evidence for stigmatic self-incompatibility, pollination induced ovule enlargement and transmitting tissue exudates in the paleoherb, Saururus cernuus L. (Saururaceae). Annals of Botany 84:507-519.

Punt W, Hoen PP, Blackmore S, Nilsson S, Le Thomas A. 2007. Glossary of pollen and spore terminology. Review of Palaeobotany and Palynology 143:1-81.

Raniecka-Bobrowska J. 1959. Tertiary seed-flora from Konin, Central Poland. Biuletyn Państwowego Instytutu Geologicznego 130:159-232.

Read PB. 2000. Geology and industrial minerals of the Tertiary basins, British Columbia. GeoFiles: British Columbia Geological Survey, p. 110.

Reid C, Reid EM. 1915. The Pliocene flora of the Dutch-Prussian border. Meded Rijkkskopsp Delftstoffen 6:1-178.

Renner SS, Grimm GW, Kapli P, Denk T. 2016. Species relationships and divergence times in beeches: New insights from the inclusion of 53 young and old fossils in a birth-death clock model. Philosophical Transactions of the Royal Society B 371: 20150135.

Sampson FB. 2000. Pollen diversity in some modern magnoliids. International Journal of Plant Sciences 161:S193-S210.

Smith SY, Stockey RA. 2007a. Establishing a fossil record for the perianthless Piperales: Saururus tuckerae sp. nov. (Saururaceae) from the Middle Eocene Princeton Chert. American Journal of Botany 94:1643-1657.

Smith SY, Stockey RA. 2007b. Pollen morphology and ultrastructure of Saururaceae. Grana 46:250-267.

Stopes MC, Fujii K. 1910. Studies on the structure and affinities of Cretaceous plants. Philosophical Transactions of the Royal Society of London B 201:1-90.

Stuchlik L, Szynkiewicz A, Lańcucka-Środoniowa M, Zastawniak E. 1990. Results of the hitherto palaeobotanical investigations of the Tertiary brown coal bed „Bełchatów ${ }^{\text {ee }}$ (Central Poland). Acta Palaeobotanica 30:259-305.

Takahashi M. 1986. Microsporogenesis in a parthenogenetic species, Houttuynia cordata Thunb. (Saururaceae). Botanical Gazette 147:47-75.

Takahashi M. 1997. Fossil spores and pollen grain of the Cretaceous (Upper Campanian) from Sakhalin, Russia. Journal of Plant Research 110:283-298. 
471 Thomas N, Bruhl JJ, Ford A, Weston PH. 2014. Molecular dating of Winteraceae reveals a

472

473

474

475

476

477

478

479

480

481

482

483

484

485

486

487

488

489

490

491

492

493

494

495

496

497

498

499

500

501

502

503

504

505

506 complex biogeographical history involving both ancient Gondwanan vicariance and longdistance dispersal. Journal of Biogeography 41:894-904.

Van Boskirk MC. 1998. The flora of the Eagle Formation and its significance for Late Cretaceous floristic evolution. Ph.D. thesis, Yale University.

Xi Y-z. 1980. Studies of pollen morphology and its systematic position in the order Piperales. Acta Botanica Sinica 22:323-329.

Zetter R. 1989. Methodik und Bedeutung einer routinemäßig kombinierten lichtmikroskopischen und rasterelektonenmikroskopischen Untersuchung fossiler Mikrofloren. Courier Forschungsinstitut Senckenberg 109:41-50.

Zetter R. 2006. The Middle Eocene microflora of the Princeton chert of southern British Columbia (Canada). 7th European Palaeobotany-Palynology Conference Program and abstracts. Prague: National Museum, p. 163 [abstract].

Zetter R, Hesse M, Huber KH. 2002. Combined LM, SEM and TEM studies of Late Cretaceous pollen and spores from Gmünd, Lower Austria. Stapfia 80:201-230.

\section{Text to Figures and Tables}

Figure 1. Practical shortcoming of cladistic classification for naming fossil and extant members of phylogenetic lineages (clades) using binominals. Shown are schematic phenograms using the current systematic-phylogenetic framework for extant taxa of the family Saururaceae (Massoni, Couvreur \& Sauquet 2015b). A) Cladistic classification of Saururaceae accepting only holophyletic (Ashlock 1971), i.e. inclusively monophyletic groups: All organisms descending from a certain common ancestor are addressed by the same genus name. All stem fossils must be named 'Saururaceae gen. et spec. indet.', unless there is conclusive evidence that they represent extinct sister lineages with no ancestor-descendant relationship to the extant genera (triggering the erection of a new genus) or belong to the stem or crown lineages of an extant genus. B) Evolutionary classification, accepting groups with inclusive (holophyla) and exclusive (paraphyla) common origins, i.e. are monophyletic according Haeckel (1866). All fossil taxa can be named using binominals, either by extending acurrentday holophyletic genus to include ancestral members of Saururaceae with equally primitive morphology, which then becomes paraphyletic by definition (e.g. Saururus), or by introducing genera to collect stem fossils ancestral to more than a single, extant and holophyletic genus (e.g. the tentative "Protosaururus" to collect fossils with Saururus-like morphology that are older than the presumed split between Saururus and Gymnothecalineages). Such extinct genera are also paraphyletic by definition. Shading signifies the extent 
507

508

509

510

511

512

513

514

515

516

517

518

519

520

521

522

523

524

525

526

527

528

529

530

531

532

533

534

535

536

537

of each (potential) genus, dark shading the modern circumscription based on molecular data (i.e. descendants of the MRCA of all extant species of the genus). Abbreviations: CA, common ancestor; MRCA, most recent common ancestor; EAS, East Asia; EAM, Eastern North America; SAS; South Asia (Indian Peninsula); WAM, Western North America.

Figure 2. SEM micrographs of Saururus aquilae sp. nov. from the Upper Cretaceous (Campanian, 82-81 Ma) of Wyoming, western USA. A) Holotype, IPUW 7513/101; pollen grain in distal polar view, showing sulcus, microechini densely packed. B) Paratype, IPUW 7513/102; pollen grain in distal polar view, showing sulcus, microechini segregated. C) Paratype, IPUW 7513/103; pollen grain in equatorial view, showing sulcus. D) Paratype, IPUW 7513/104; pollen grain in equatorial view, showing sulcus. E) Paratype, IPUW 7513/105; pollen grain in proximal polar view. F) Paratype, IPUW 7513/106, pollen grain in proximal polar view. G) Paratype, IPUW 7513/107, pollen grain in proximal polar view. H) Paratype, IPUW 7513/108; pollen grain in proximal polar view, with eroded parts revealing the columellae. Scale bars: $1 \mu \mathrm{m}$.

Figure 3. SEM micrographs of Saururus aquilae sp. nov. from the Upper Cretaceous (Campanian, 82-81 Ma) of Wyoming, western USA. A) Paratype, IPUW 7513/109; pollen grain in proximal polar view, large perforations. B) Close-up of Figure $2 \mathrm{H}$, showing densely packed columellae in an area of surface erosion. C) Close-up of Figure 2G, showing tiny perforations. D) Paratype, IPUW 7513/110; close-up showing small circular perforations filled with columellae. E) Close-up of Figure 2D, showing irregular and lobate perforations and free-standing columellae. F) Close-up of Figure 2E, showing small irregular perforations and free-standing columellae. G) Close-up of Figure 3A, showing large circular to elliptic perforations and free-standing columellae. H) Paratype, IPUW 7513/111; close-up showing large irregular perforations and free-standing columellae. Scale bars: $1 \mu \mathrm{m}$.

Figure 4. SEM and LM micrographs of Saururus aquilae sp. nov. (A-G; Campanian; Wyoming) and LM micrographs of Saururus tuckerae (H; middle Eocene; Princeton, B.C.) A) Close-up of Figure 2B, showing sulcus membrane, segregated microechini. B) Close-up of Figure 2B, showing sulcus membrane, segregated microechini. C) Close-up of Figure 2C, showing 
538

539

540

541

542

543

544

545

546

547

548

549

550

551

552

553

554

555

556

557

558

559

560

561

562

563

564

565

566

567

568

sulcus membrane, densely packed microechini. D) Close-up of Figure 2D, showing sulcus membrane, densely packed microechini. E) Close-up of Figure 2A (holotype), showing sulcus membrane. F) Close-up of Figure 4E (holotype), showing densely packed microechini. G) Saururus aquilae sp. nov. pollen in LM. H) Saururus tuckerae pollen in LM. Scale bars: $1 \mu \mathrm{m}$ in $\mathrm{A}-\mathrm{F}, 10 \mu \mathrm{m}$ in $\mathrm{G}, \mathrm{H}$.

Figure 5. SEM micrographs of Saururus tuckerae pollen from the middle Eocene (c. $48 \mathrm{Ma}$ ) of Princeton, B.C., western Canada. A) Pollen grain (IPUW 7513/112) in distal polar view, showing sulcus, microechini segregated. B) Pollen grain (IPUW 7513/113) in distal polar view, showing sulcus. C) Pollen grain (IPUW 7513/114) in distal polar view, showing sulcus. D) Pollen grain (IPUW 7513/115) in oblique equatorial view, showing sulcus. E) Pollen grain (IPUW 7513/116) in equatorial view, showing sulcus and sulcus membrane. F) Pollen grain (IPUW 7513/117) in proximal polar view. G) Pollen grain (IPUW 7513/118) in proximal polar view. H) Pollen grain (IPUW 7513/119) in proximal polar view. Scale bars: $1 \mu \mathrm{m}$.

Figure 6. SEM micrographs of Saururus tuckerae pollen from the middle Eocene (c. $48 \mathrm{Ma}$ ) of Princeton, B.C., western Canada. A) Pollen grains preserved in a clump (IPUW 7513/120). B) Pollen grains preserved in a clump (IPUW 7513/121). C) Pollen grain, close-up of Figure 5B, showing small circular to elliptic perforations filled with free-standing columellae. D) Closeup of Figure 5H, showing small irregular to lobate perforations. E) Close-up of Figure 5D, showing small irregular to lobate perforations, some with up to 6 free-standing columellae. F) Pollen grain, IPUW 7513/122; close-up showing irregular to lobate perforations. G) Close-up of Figure 6B, showing irregular to lobate perforations with many free-standing columellae. H) Close-up of pollen (IPUW 7513/123) grain showing irregular to lobate perforations. Scale bars: $1 \mu \mathrm{m}$.

Figure 7. SEM micrographs of Saururus tuckerae (A-D; middle Eocene; Princeton, B.C.) and Saururus stoobensis sp. nov. from the Miocene Opencast clay pit, Stoob-Warasdorf-Forest, Burgenland, Austria (E-G). A) Close-up of Figure 5A, showing microechinate colpus membrane, microechini segregated. B) Close-up of Figure 5A, showing colpus membrane, microechini segregated. C) Close-up of Figure 5B, showing microechinate membrane. D) 
569 Close-up of Figure 6A, showing colpus membrane. E) Saururus stoobensis sp. nov. holotype,

570

571

572

573

574

575

576

577

578

579

580

581

582

583

584

585

586

587

588

589

590

591

592

593

594

595

596

597

598 IPUW 7513/124; grain (arrow) attached to a pollen grain of Apiaceae illustrating the size difference. F) Close-up of Figure 7E, overview of pollen. G) Close-up of Figure 7F, showing perforate sculpture with relatively few and tiny perforations. Scale bars: $1 \mu \mathrm{m}$ in A-D, F, G, $10 \mu \mathrm{m}$ in $\mathrm{E}$.

Figure 8. Mapping of the fossil record (circles, stars) of Saururaceae on dated phylogenies (Bayesian uncorrelated clock; included in Massoni, Couvreur \& Sauquet 2015a). Oldest fossils of the Winteraceae are shown for comparison. Pink: North American fossils; cyan: western Eurasian (Central Europe to western Siberia) fossils; yellow: East Asian fossils; stars: fossil pollen described here. Blue bars represent the $95 \%$ highest posterior density (HPD) intervals of the minimum age and maximum age scenarios; node heights are averages (medians are indicated by deep blue bars in the HPD intervals). Branch labels show posterior probabilities $(\mathrm{PP})<1.0$ (all other branches have PP $=1.00$ ), red branches highlight topological conflict between the chronograms (probably due to incomprehensive Bayesian runs getting stuck in local suboptima, since all analyses were based on the same data set).

Figure 9. Hypothetical evolution of Saururaceae pollen. Both the fossil and extant Saururus show a morphology that may be primitive within the family: all other genera differ by one or two unique, putatively derived traits. Abbreviations: PS = (normal) pollen surface; $\mathrm{SM}=$ sulcus membrane. Scale bars $=1 \mu \mathrm{m}$.

Table 1. Modern and past distribution of Saururaceae genera.

Table 2. Fossil record of Saururaceae

Table 3. Divergence age estimates for the Saururaceae subtree according to minimum and maximum age scenarios (angiosperm root fixed to max. 130 or $200 \mathrm{Ma}$; Massoni, Couvreur \& Sauquet 2015a). 
599 Table 4. Pollen features of extinct $(\dagger)$ and extant Saururaceae; unique (genus- or species-level) 600 features in bold. 


\section{Table 1 (on next page)}

Modern and past distribution of Saururaceae genera 
1 Table 1. Modern and past distribution of Saururaceae genera

\begin{tabular}{llll}
\hline Time period & North America & Western Eurasia & East Asia \\
\hline Recent & Saururus, Anemopsis & None & $\begin{array}{l}\text { Gymnotheca, Saururus, } \\
\text { Houttuynia }\end{array}$ \\
Neogene & None & $\begin{array}{l}\text { Saururus (pollen, } \\
\text { fruit/seed), }\end{array}$ & None \\
Paleogene & $\begin{array}{l}\text { Houttuynia (fruit/seed) } \\
\text { Saururus (fruit/seed) }\end{array}$ & Saururus (fruit/seed) \\
& $\begin{array}{l}\text { Saururus } \\
\text { (inflorescence with } \\
\text { in-situ pollen; and } \\
\text { dispersed pollen) }\end{array}$ & & \\
Saururus-type pollen & None & Saururopsis (wood) \\
\hline
\end{tabular}

2 
Table 2 (on next page)

Fossil record of Saururaceae 
Table 2. Fossil record of Saururaceae

2

\begin{tabular}{|c|c|c|c|c|c|}
\hline Taxon & Organ & Period (epoch) & Age in Ma & State/region, country & Reference \\
\hline \multicolumn{6}{|l|}{ North America } \\
\hline Saururus aquilae & Pollen & Late Cretaceous (Campanian) & $82-81$ & Wyoming, United States & This study \\
\hline Saururus tuckerae & $\begin{array}{l}\text { Inflorescence, } \\
\text { flowers, } \\
\text { pollen }\end{array}$ & Middle Eocene & $\sim 48$ & British Columbia, Canada & $\begin{array}{l}\text { Smith \& Stockey (2007a); } \\
\text { This study }\end{array}$ \\
\hline \multicolumn{6}{|l|}{ Western Eurasia } \\
\hline Saururus bilobatus & Fruits/seeds & Late Eocene to Pliocene & $\sim 40-2.5$ & Germany & $\begin{array}{l}\text { Reid \& Reid (1915); Mai } \\
\text { (1965); Mai (1967); Mai \& } \\
\text { Walther (1978); Mai \& } \\
\text { Walther (1985); Mai } \\
\text { (1995); Mai (1999) }\end{array}$ \\
\hline $\begin{array}{l}\text { Saururus bilobatus (incl. } \\
\text { Helitropium sp. and } \\
\text { Carpolithus sp.) }\end{array}$ & Fruits/seeds & Miocene & $\sim 23-5$ & Poland & $\begin{array}{l}\text { Raniecka-Bobrowska } \\
\text { (1959); Łańcucka- } \\
\text { Srodoniowa (1979); } \\
\text { Stuchlik et al. (1990); } \\
\text { Lesiak (1994) }\end{array}$ \\
\hline Saururus bilobatus & Fruits/seeds & Middle Miocene (Langhian) & $\sim 16-14$ & Denmark & Friis $(1985)$ \\
\hline Saururus stoobensis & Pollen & $\begin{array}{l}\text { Middle Miocene (late } \\
\text { Serravallian; Sarmatian) }\end{array}$ & $\sim 12$ & Austria & $\begin{array}{l}\text { Ferguson, Zetter \& } \\
\text { Paudayal (2007) as } \\
\text { "Saururipollis sp." (nomen } \\
\text { nudum); formalized in this } \\
\text { study }\end{array}$ \\
\hline Houttuynia bavarica & Fruits/seeds & Early Miocene & $\sim 23-16$ & Germany & Mai (1999) \\
\hline \multicolumn{6}{|l|}{ East Asia } \\
\hline Saururopsis niponensis & Wood & Late Cretaceous & $>66$ & Hokkaido, Japan & Stopes \& Fujii (1910) \\
\hline $\begin{array}{l}\text { Saururus bilobatus (as } \\
\text { Carpolithus bilobatus) }\end{array}$ & Fruits/seeds & Oligocene & $\sim 34-23$ & Western Siberia, Russia & $\begin{array}{l}\text { Dorofeyev (1963); Nikitin } \\
\text { (1965) }\end{array}$ \\
\hline
\end{tabular}




\section{Table 3(on next page)}

Divergence age estimates for the Saururaceae subtree according to minimum and maximum age scenarios (angiosperm root fixed to max. 130 or $200 \mathrm{Ma}$; Massoni, Couvreur \& Sauquet 2015a)

Abbreviations: $\mathrm{MRCA}=$ most recent common ancestor $; \mathrm{Ma}=$ Million years ago. 
1 Table 3. Divergence age estimates for the Saururaceae subtree according to minimum and 2 maximum age scenarios (angiosperm root fixed to max. 130 or $200 \mathrm{Ma}$; Massoni, Couvreur \& 3 Sauquet 2015a). Abbreviations: MRCA $=$ most recent common ancestor; $\mathrm{Ma}=$ Million years ago. 4

Node Angiosperm root fixed to Max. $130 \mathrm{Ma}$

Max. $200 \mathrm{Ma}$

Saururaceae root 97.0-60.4 (median: 78.3) 117.3-80.3 (median: 99.8)

Saururaceae crown 75.3-46.7 (median: 58.9) $\quad 80.8-48.6$ (median: 62.8)

MRCA of Gymnotheca+Saururus

62.1-44.3 (median: 49.4) 65.6-44.3 (median: 50.6)

MRCA of Anemopsis +Houttuynia

64.5-10.3 (median: 37.1) 72.5-26.8 (median: 49.5)

5 


\section{Table 4(on next page)}

Pollen features of extinct and extant Saururaceae

Unique (genus- or species-level) features highlighted by bold font. Measurements and features are based on Xi (1980), Takahashi (1986), Pontieri \& Sage (1999), Sampson (2000), Furness et al. (2002), Smith \& Stockey (2007a, 2007b), Lu et al. (2015) and our own observations. <!--[if !supportAnnotations]--> <!--[endif]--> Abbreviations: E, diameter in equatorial view (length of polar axis); P, diameter in polar view (length of equatorial axis) <!-[if !supportAnnotations]--><!--[endif]-->; SEM, scanning-electron microscopy. 
1 Table 4. Pollen features of extinct $(\dagger)$ and extant Saururaceae; unique (genus- or species-level) features in bold.

2 Abbreviations: E, equatorial diameter; P, polar axis); SEM, scanning-electron microscopy

\begin{tabular}{|c|c|c|c|c|c|c|c|c|c|c|}
\hline Species & $\begin{array}{l}\text { Distibution/ } \\
\text { provenance }\end{array}$ & $\begin{array}{l}\text { E } \\
(\mu \mathrm{m} ; \\
\text { SEM) }\end{array}$ & $\begin{array}{l}\mathbf{P} \\
(\mu \mathrm{m} ; \\
\text { SEM })\end{array}$ & $\begin{array}{l}\text { Surface } \\
\text { sculpture } \\
\text { (SEM) }\end{array}$ & $\begin{array}{l}\text { Sulcus } \\
\text { membrane } \\
\text { (SEM) }\end{array}$ & $\begin{array}{l}\text { Perforations } \\
\text { per } 4 \mu^{2} \\
\text { proximal face }\end{array}$ & $\begin{array}{l}\text { Size and } \\
\text { outline of } \\
\text { perforations }\end{array}$ & $\begin{array}{l}\text { Free- } \\
\text { standing or } \\
\text { protruding } \\
\text { columellae }\end{array}$ & $\begin{array}{l}\text { Exine } \\
\text { thickness, } \\
\text { mean }(\mu \mathrm{m})\end{array}$ & $\begin{array}{l}\text { Nexine } \\
\text { thickness, } \\
\text { mean }(\mu \mathrm{m})\end{array}$ \\
\hline $\begin{array}{l}\text { Anemopsis } \\
\text { californica }\end{array}$ & $\begin{array}{l}\text { SW U.S., } \\
\text { NW Mexico }\end{array}$ & $12-13$ & $5-6$ & $\begin{array}{l}\text { Perforate, } \\
\text { granulate }\end{array}$ & $\begin{array}{l}\text { Echinate, } \\
\text { rugulate }\end{array}$ & $7-9$ & $\begin{array}{l}\text { Tiny; circular, } \\
\text { elliptic, } \\
\text { irregular }\end{array}$ & up to 6 & 0.47 & 0.20 \\
\hline $\begin{array}{l}\text { Gymnotheca } \\
\text { chinenis }\end{array}$ & $\begin{array}{l}\text { SW and S } \\
\text { China, } \\
\text { Vietnam }\end{array}$ & $9-10$ & $4-5$ & $\begin{array}{l}\text { Perforate, } \\
\text { striate, } \\
\text { nanoechinate }\end{array}$ & Microechinate & $18-20$ & $\begin{array}{l}\text { Small; circular, } \\
\text { elliptic }\end{array}$ & No & 0.55 & 0.18 \\
\hline $\begin{array}{l}\text { Gymnotheca } \\
\text { involucrata }\end{array}$ & $\begin{array}{l}\text { S Sichuan (S } \\
\text { China) }\end{array}$ & $10-11$ & $5-6$ & $\begin{array}{l}\text { Perforate, } \\
\text { striate, } \\
\text { nanoechinate }\end{array}$ & Microechinate & $17-19$ & $\begin{array}{l}\text { Small; circular, } \\
\text { elliptic }\end{array}$ & No & 0.54 & 0.15 \\
\hline $\begin{array}{l}\text { Houttuynia } \\
\text { cordata }\end{array}$ & $\mathrm{S}$ and $\mathrm{E}$ Asia & $13-14$ & $8-9$ & $\begin{array}{l}\text { Perforate, } \\
\text { psilate }\end{array}$ & Microechinate & $10-12$ & $\begin{array}{l}\text { Tiny; circular, } \\
\text { elliptic, } \\
\text { irregular }\end{array}$ & & & \\
\hline $\begin{array}{l}\text { Saururus } \\
\text { cernuus }\end{array}$ & E U.S. & $10-13$ & $5-6$ & $\begin{array}{l}\text { Perforate, } \\
\text { granulate }\end{array}$ & Microechinate & $7-9$ & $\begin{array}{l}\text { Tiny; circular, } \\
\text { elliptic, } \\
\text { irregular }\end{array}$ & $2-4$ & 0.49 & 0.20 \\
\hline $\begin{array}{l}\text { Saururus } \\
\text { chinensis }\end{array}$ & $\mathrm{S}$ and $\mathrm{E}$ Asia & $11-12$ & $4-5$ & $\begin{array}{l}\text { Perforate, } \\
\text { psilate, } \\
\text { indistinctly } \\
\text { rugulate }\end{array}$ & Microechinate & $6-8$ & $\begin{array}{l}\text { Tiny; circular, } \\
\text { elliptic, } \\
\text { irregular, lobate }\end{array}$ & $3-4$ & 0.47 & 0.24 \\
\hline $\begin{array}{l}\dagger \text { Saururus } \\
\text { aquilae }\end{array}$ & NW USA & $6-11$ & $3-5$ & $\begin{array}{l}\text { Perforate, } \\
\text { psilate to } \\
\text { granulate }\end{array}$ & $\begin{array}{l}\text { Microechinate, } \\
\text { echini can be } \\
\text { densely packed }\end{array}$ & $20-25$ & $\begin{array}{l}\text { Tiny to small; } \\
\text { circular, elliptic, } \\
\text { irregular, } \\
\text { irregular- } \\
\text { elongated, } \\
\text { lobate }\end{array}$ & $1-6$ & 0.40 & 0.14 \\
\hline $\begin{array}{l}\text { † Saururus } \\
\text { tuckerae }\end{array}$ & SW Canada & $6-11$ & $3-5$ & $\begin{array}{l}\text { Perforate, } \\
\text { psilate to } \\
\text { granulate }\end{array}$ & $\begin{array}{l}\text { Microechinate, } \\
\text { echini } \\
\text { segregated }\end{array}$ & $23-26$ & $\begin{array}{l}\text { Tiny to small; } \\
\text { circular, elliptic, } \\
\text { irregular, } \\
\text { irregular- } \\
\text { elongated, } \\
\text { lobate }\end{array}$ & $2-6$ & 0.37 & 0.15 \\
\hline $\begin{array}{l}\dagger \text { Saururus } \\
\text { stoobensis }\end{array}$ & Austria & $10-11$ & $4-5$ & $\begin{array}{l}\text { Perforate, } \\
\text { psilate to } \\
\text { granulate }\end{array}$ & Not observed & $7-10$ & $\begin{array}{l}\text { Tiny; circular, } \\
\text { elliptic, } \\
\text { irregular, lobate }\end{array}$ & $2-4$ & $\begin{array}{l}\text { Not } \\
\text { observed }\end{array}$ & $\begin{array}{l}\text { Not } \\
\text { observed }\end{array}$ \\
\hline
\end{tabular}


3 Note: Measurements and features from/based on Xi (1980), Takahashi (1986), Pontieri \& Sage (1999), Sampson (2000), Furness et al.

4 (2002), Smith \& Stockey (2007a, 2007b), Lu et al. (2015) and our own observations. 


\section{Figure 1}

Practical shortcoming of cladistic classification for naming fossil and extant members of phylogenetic lineages (clades) using binominals

Shown are schematic phenograms using the current systematic-phylogenetic framework for extant taxa of the family (Massoni, Couvreur \& Sauquet 2015b). (A) Cladistic classification of Saururaceae accepting only holophyletic (Ashlock 1971), i.e. inclusively monophyletic groups: All organisms descending from a certain common ancestor are addressed by the same genus name. All stem fossils must be named 'Saururaceae gen. et spec. indet.', unless there is conclusive evidence that they represent extinct sister lineages with no ancestordescendant relationship to the extant genera (triggering the erection of a new genus) or belong to the stem or crown lineages of an extant genus. (B) Evolutionary classification, accepting groups with inclusive (holophyla) and exclusive (paraphyla) common origins, i.e. are monophyletic according Haeckel (1866). All fossil taxa can be named using binominals, either by extending a today holophyletic genus to include ancestral members of Saururaceae with equally primitive morphology, which then becomes paraphyletic by definition (e.g. Saururus), or by introducing genera to collect stem fossils ancestral to more than a single, extant and holophyletic genus (e.g. the tentative Protosaururus to collect fossils with Saururus-like morphology that are older than the presumed split between Saururus and Gymnotheca-lineages). Such extinct genera are also paraphyletic by definition. Shading signifies the extent of each (potential) genus, dark shading the modern circumscription based on molecular data (i.e. descendants of the MRCA of all extant species of the genus). Abbreviations: CA, common ancestor; MRCA, most recent common ancestor; EAS, East Asia; EAM, Eastern North America; SAS; South Asia (Indian Peninsula); WAM, Western North America. 
(A)

\section{Morphology}

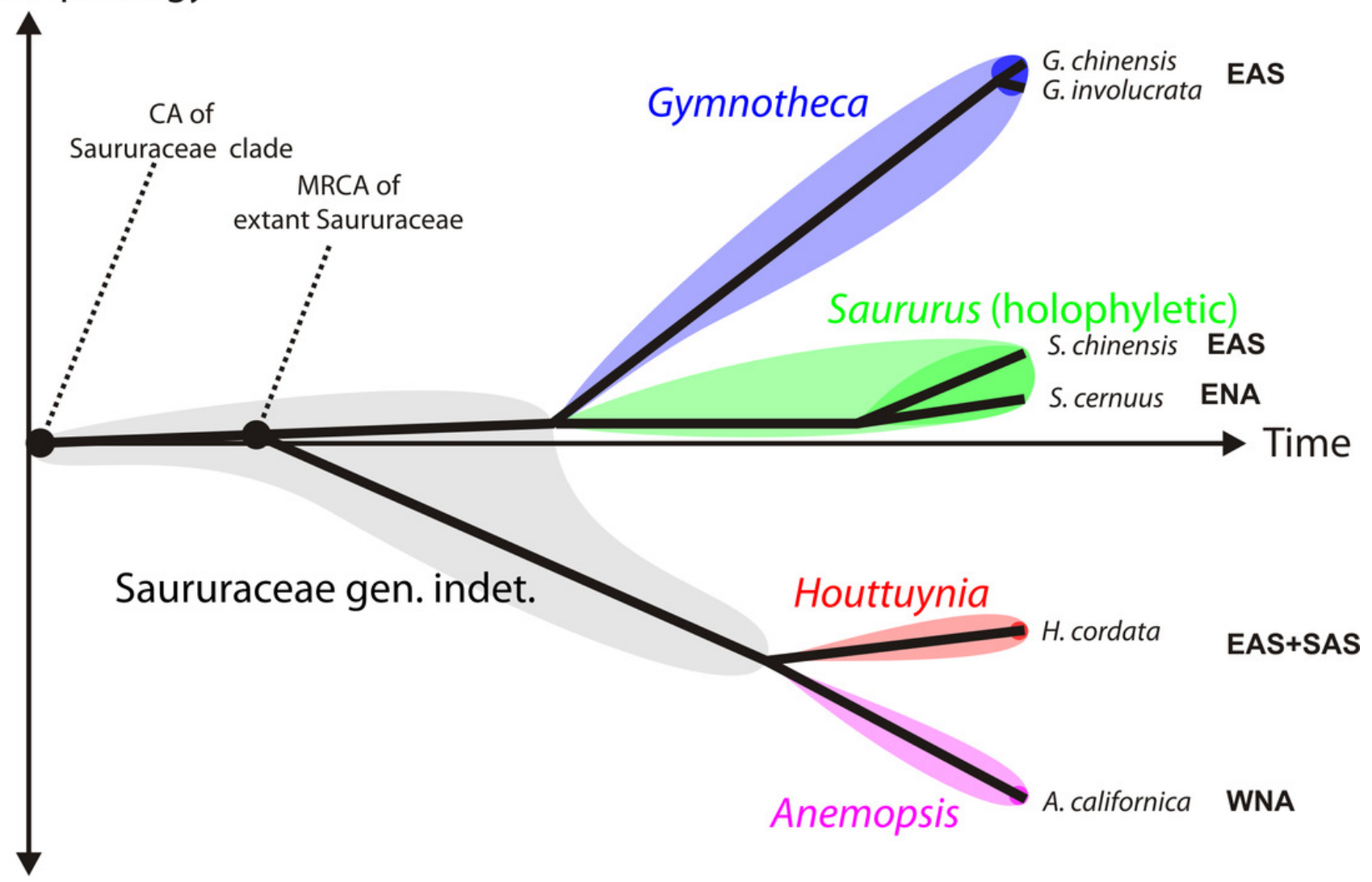

(B)

\section{Morphology}

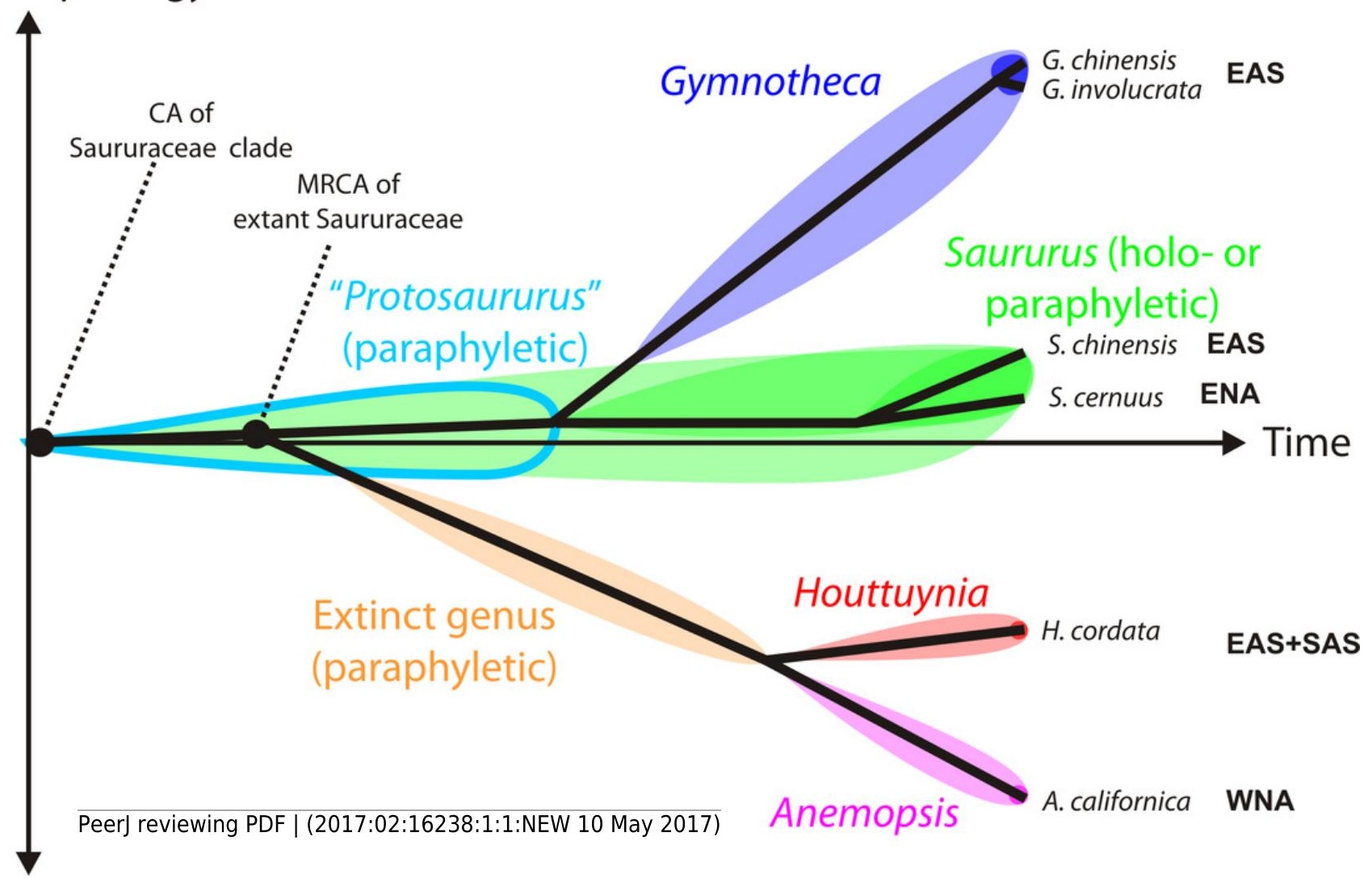




\section{Figure 2}

SEM micrographs of Saururus aquilae sp. nov. from the Upper Cretaceous (Campanian, 82-81 Ma) of Wyoming, western USA

\section{A) Holotype, IPUW 7513/101; pollen grain in distal polar view, showing sulcus, microechini densely packed. B) Paratype, IPUW 7513/102; pollen grain in distal polar view, showing sulcus, microechini segregated. C) Paratype, IPUW 7513/103;}

pollen grain in equatorial view, showing sulcus. D) Paratype, IPUW 7513/104; pollen grain in equatorial view, showing sulcus. E) Paratype, IPUW 7513/105; pollen grain in proximal polar view. F) Paratype, IPUW 7513/106, pollen grain in proximal polar view. G) Paratype, IPUW 7513/107, pollen grain in proximal polar view. H) Paratype, IPUW 7513/108; pollen grain in proximal polar view, with eroded parts revealing the columellae. Scale bars: $1 \mu \mathrm{m}$. 


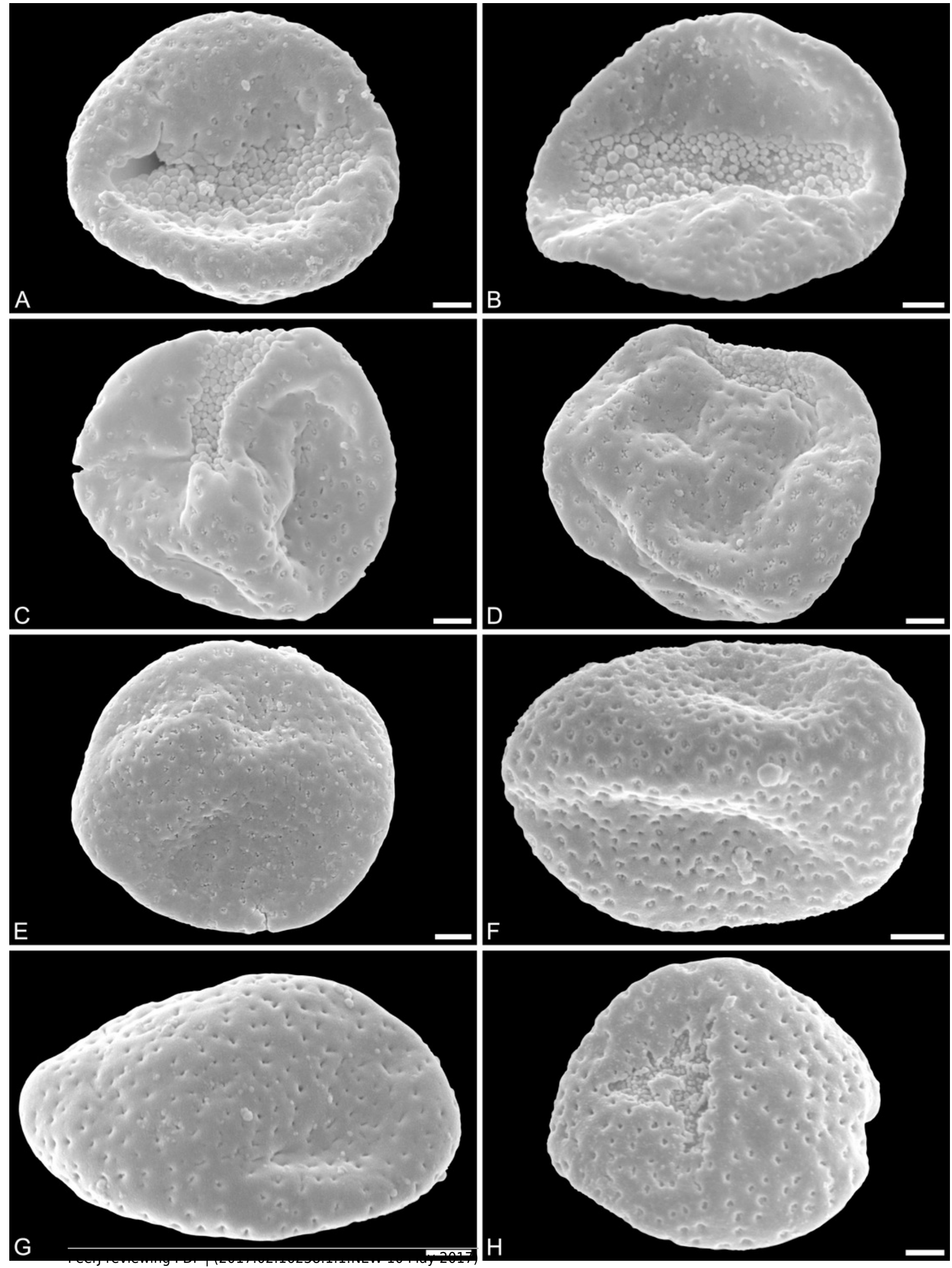




\section{Figure 3}

SEM micrographs of Saururus aquilae sp. nov. from the Upper Cretaceous (Campanian, 82-81 Ma) of Wyoming, western USA

A) Paratype, IPUW 7513/109; pollen grain in proximal polar view, large perforations. B) Close-up of Figure $2 \mathrm{H}$, showing densely packed columellae in an area of surface erosion. C) Close-up of Figure 2G, showing tiny perforations. D) Paratype, IPUW 7513/110; close-up showing small circular perforations filled with columellae. E) Close-up of Figure 2D, showing irregular and lobate perforations and free-standing columellae. F) Close-up of Figure 2E, showing small irregular perforations and free-standing columellae. G) Close-up of Figure 3A, showing large circular to elliptic perforations and free-standing columellae. H) Paratype, IPUW 7513/111; close-up showing large irregular perforations and free-standing columellae. Scale bars: $1 \mu \mathrm{m}$. 


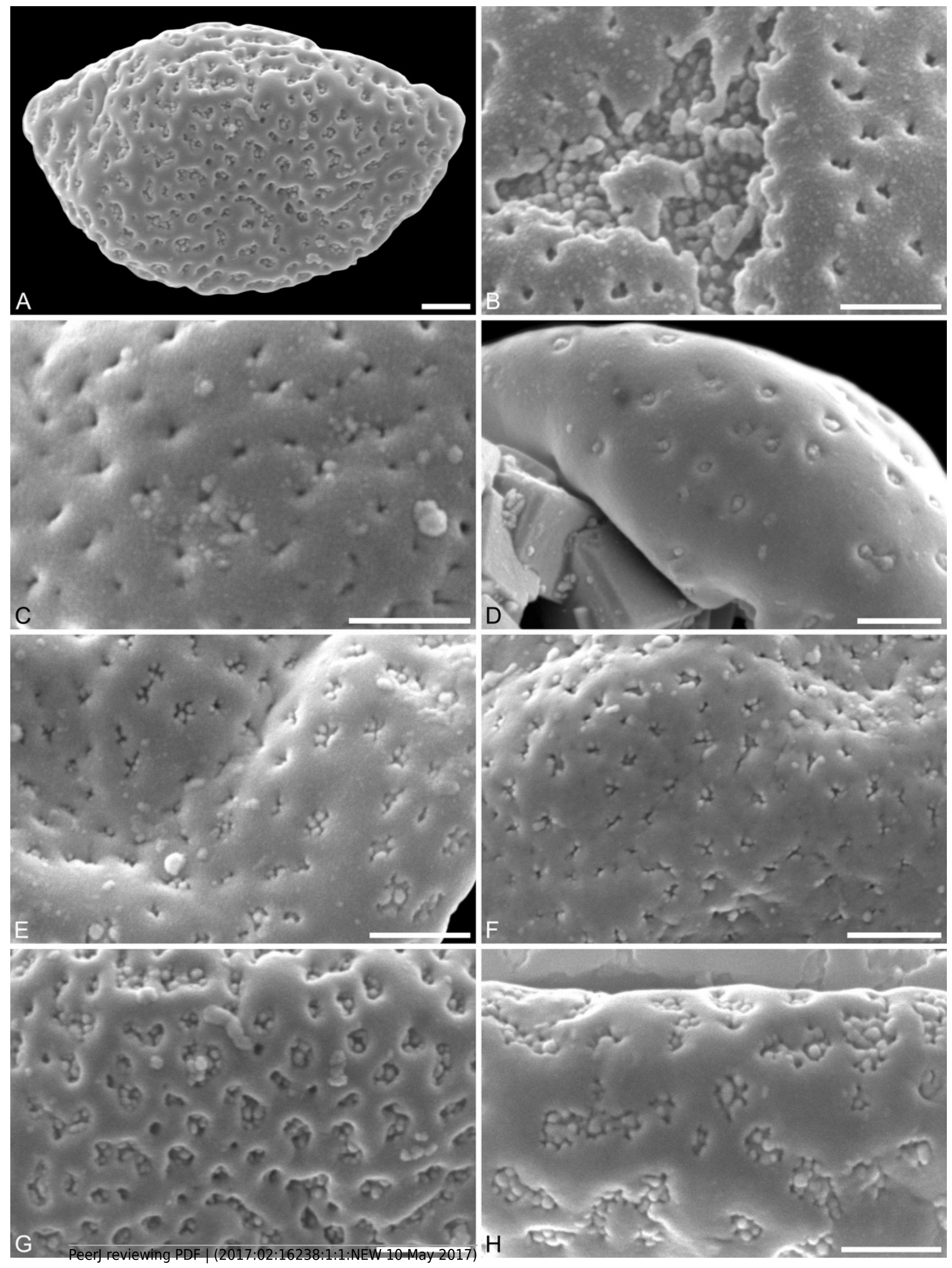




\section{Figure 4}

SEM and LM micrographs of Saururus aquilae sp. nov. (A-G; Campanian; Wyoming) and LM micrographs of Saururus tuckerae (H; middle Eocene; Princeton, B.C.)

A) Close-up of Figure 2B, showing sulcus membrane, segregated microechini. B) Close-up of Figure 2B, showing sulcus membrane, segregated microechini. C) Close-up of Figure 2C, showing sulcus membrane, densely packed microechini. D) Close-up of Figure 2D, showing sulcus membrane, densely packed microechini. E) Close-up of Figure $2 \mathrm{~A}$ (holotype), showing sulcus membrane. F) Close-up of Figure 4E (holotype), showing densely packed microechini. G) Saururus aquilae sp. nov. pollen in LM. H) Saururus tuckerae pollen in LM. Scale bars: Scale bars: $1 \mu \mathrm{m}$ in A-F, $10 \mu \mathrm{m}$ in $\mathrm{G}, \mathrm{H}$. 

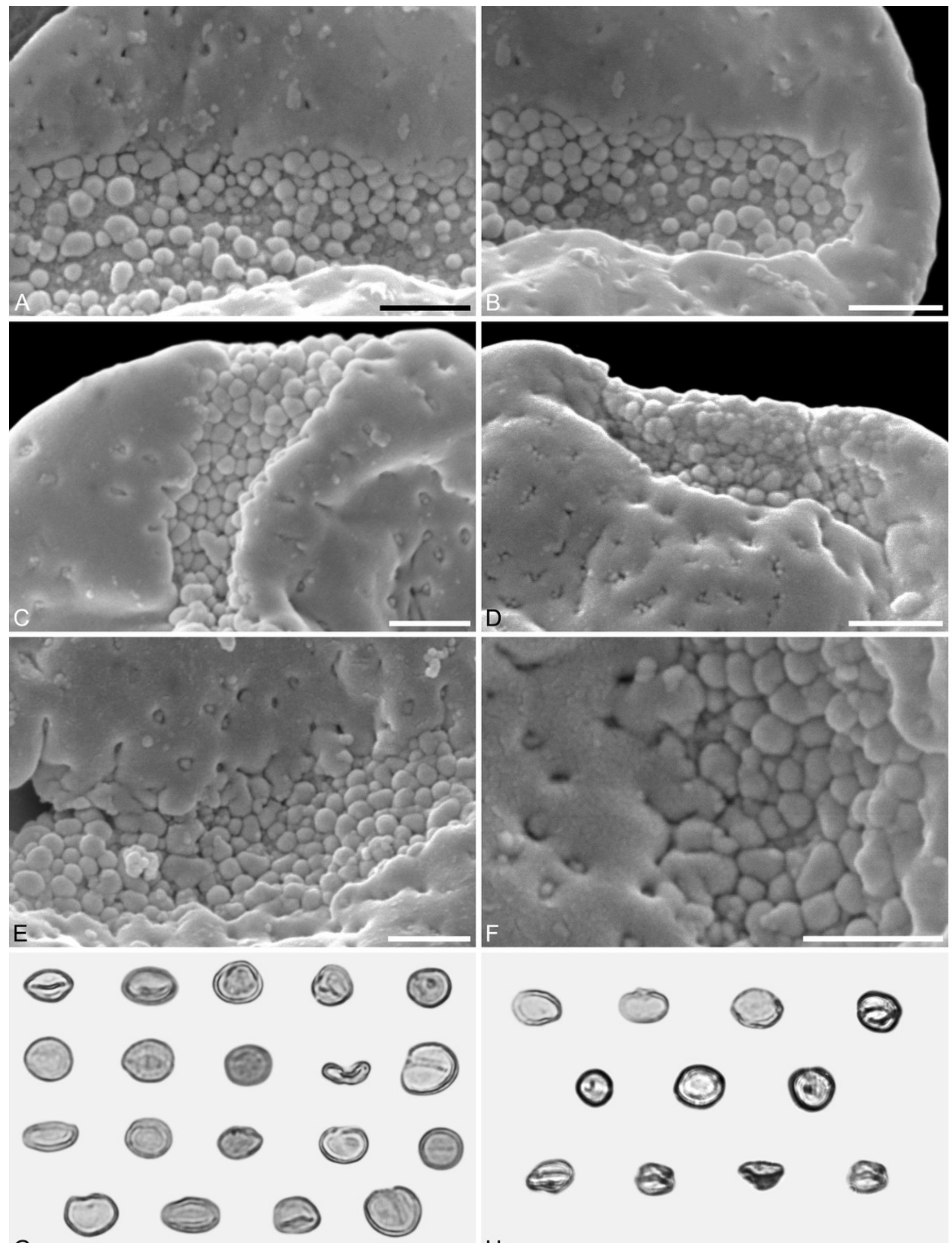

$\Leftrightarrow \theta \approx$ 


\section{Figure 5}

SEM micrographs of Saururus tuckerae pollen from the middle Eocene (c. $48 \mathrm{Ma}$ ) of Princeton, B.C., western Canada

A) Pollen grain (IPUW 7513/112) in distal polar view, showing sulcus, microechini segregated.

B) Pollen grain (IPUW 7513/113) in distal polar view, showing sulcus. C) Pollen grain (IPUW 7513/114) in distal polar view, showing sulcus. D) Pollen grain (IPUW 7513/115) in oblique equatorial view, showing sulcus. E) Pollen grain (IPUW 7513/116) in equatorial view, showing sulcus and sulcus membrane. F) Pollen grain (IPUW 7513/117) in proximal polar view. G) Pollen grain (IPUW 7513/118) in proximal polar view. H) Pollen grain (IPUW 7513/119) in proximal polar view. Scale bars: $1 \mu \mathrm{m}$.

*Note: Auto Gamma Correction was used for the image. This only affects the reviewing manuscript. See original source image if needed for review. 

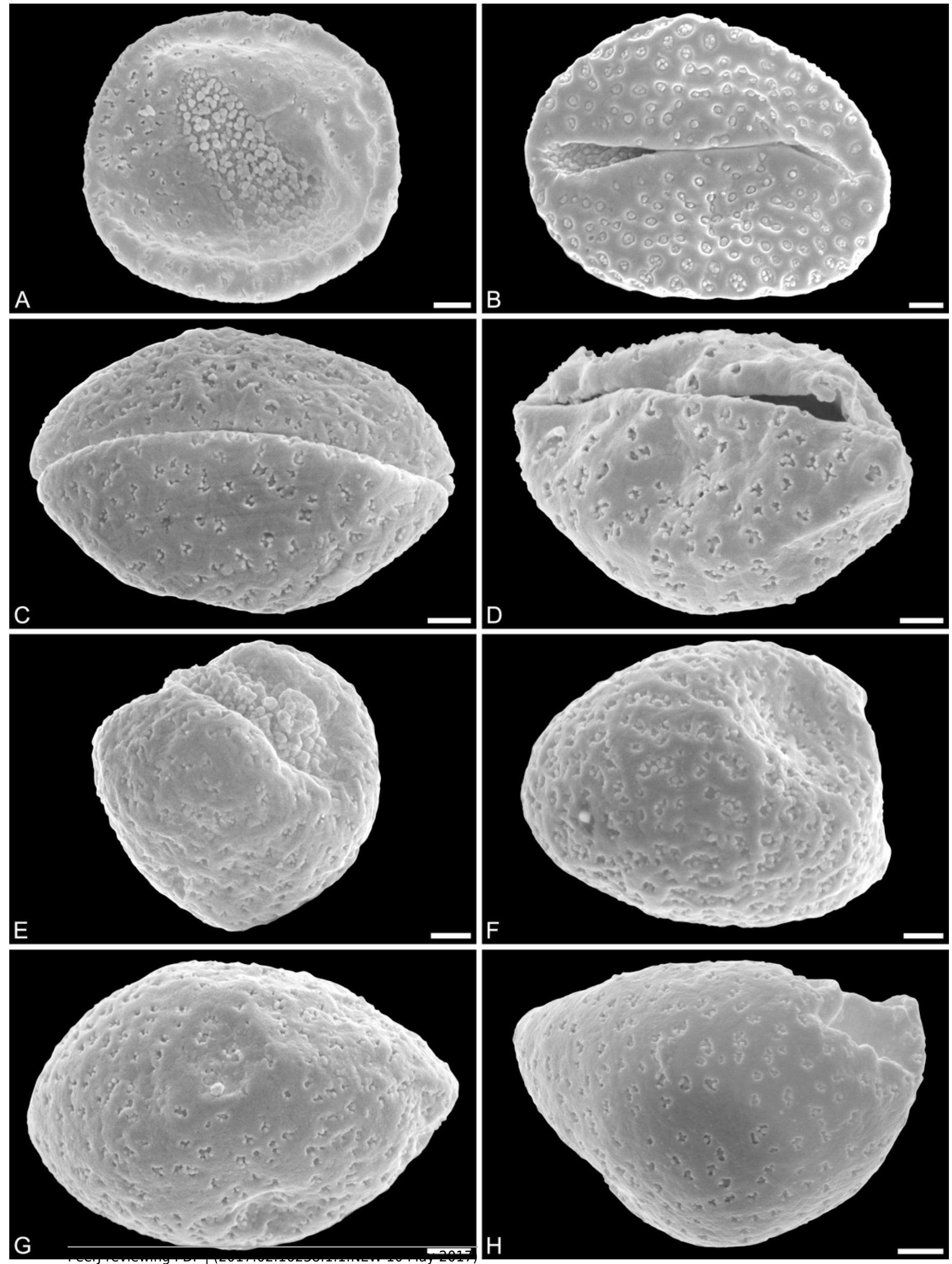


\section{Figure 6}

SEM micrographs of Saururus tuckerae pollen from the middle Eocene (c. $48 \mathrm{Ma}$ ) of Princeton, B.C., western Canada

A) Pollen grains preserved in a clump (IPUW 7513/120). B) Pollen grains preserved in a clump (IPUW 7513/121). C) Pollen grain, close-up of Figure 5B, showing small circular to elliptic perforations filled with free-standing columellae. D) Close-up of Figure $5 \mathrm{H}$, showing small irregular to lobate perforations. E) Close-up of Figure 5D, showing small irregular to lobate perforations, some with up to 6 free-standing columellae. F) Pollen grain, IPUW 7513/122; close-up showing irregular to lobate perforations. G) Close-up of Figure 6B, showing irregular to lobate perforations with up free-standing columellae. H) Close-up of pollen (IPUW 7513/123) grain showing irregular to lobate perforations. Scale bars: $1 \mu \mathrm{m}$. 

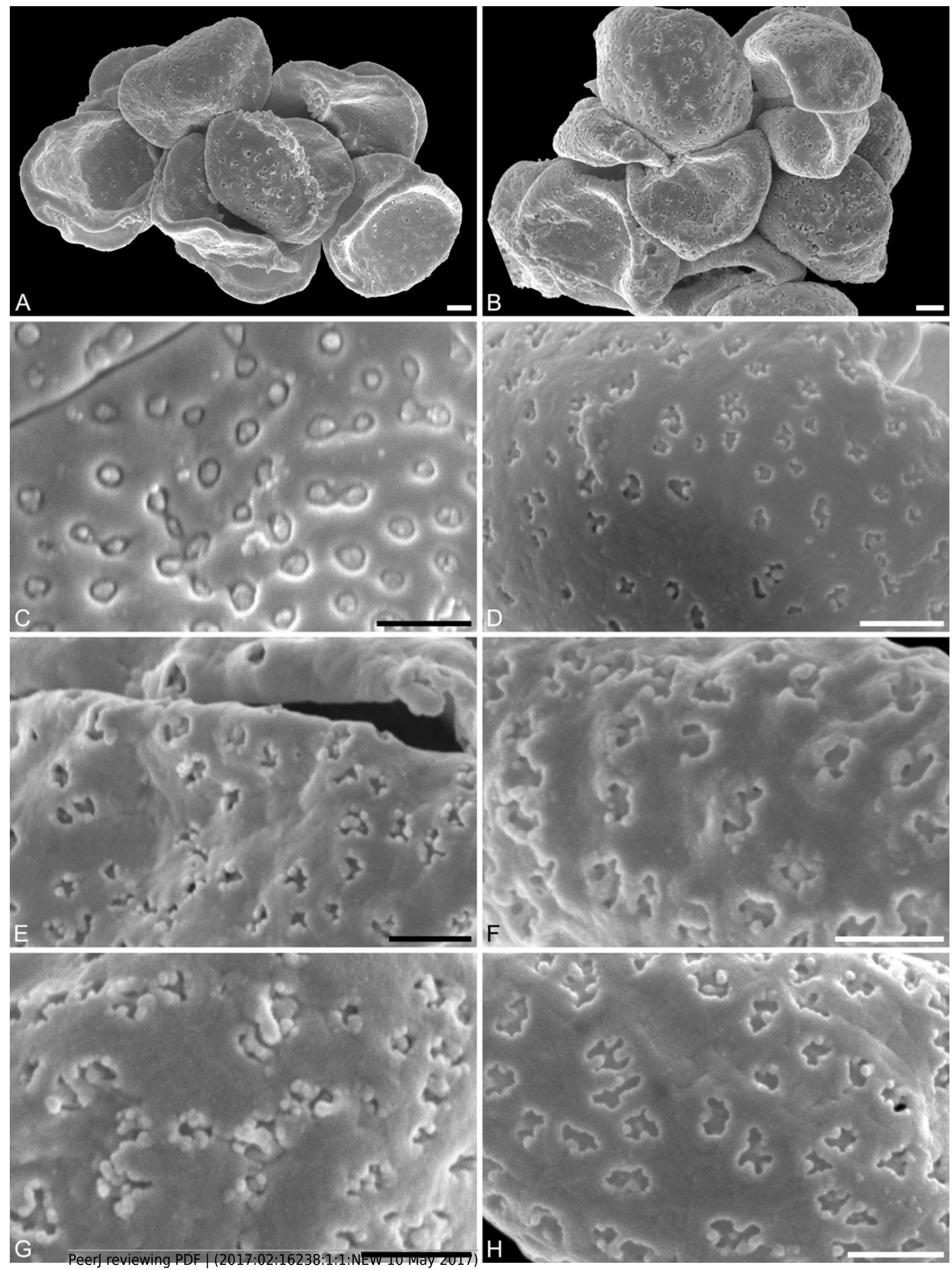


\section{Figure 7}

SEM micrographs of Saururus tuckerae (A-D; middle Eocene; Princeton, B.C.) and Saururus stoobensis sp. nov. from the Miocene Opencast clay pit, Stoob-WarasdorfForest, Burgenland, Austria (E-G)

A) Close-up of Figure 5A, showing microechinate colpus membrane, microechini segregated.

B) Close-up of Figure 5A, showing colpus membrane, microechini segregated. C) Close-up of Figure 5B, showing microechinate membrane. D) Close-up of Figure 6A, showing colpus membrane. E) Saururus stoobensis sp. nov. holotype, IPUW 7513/124; grain (arrow) attached to a pollen grain of Apiaceae illustrating the size difference. F) Close-up of Figure 7E, overview of pollen. G) Close-up of Figure $7 F$, showing perforate sculpture with relatively few and tiny perforations. Scale bars: $1 \mu \mathrm{m}$ in A-D, F, G, $10 \mu \mathrm{m}$ in $\mathrm{E}$. 

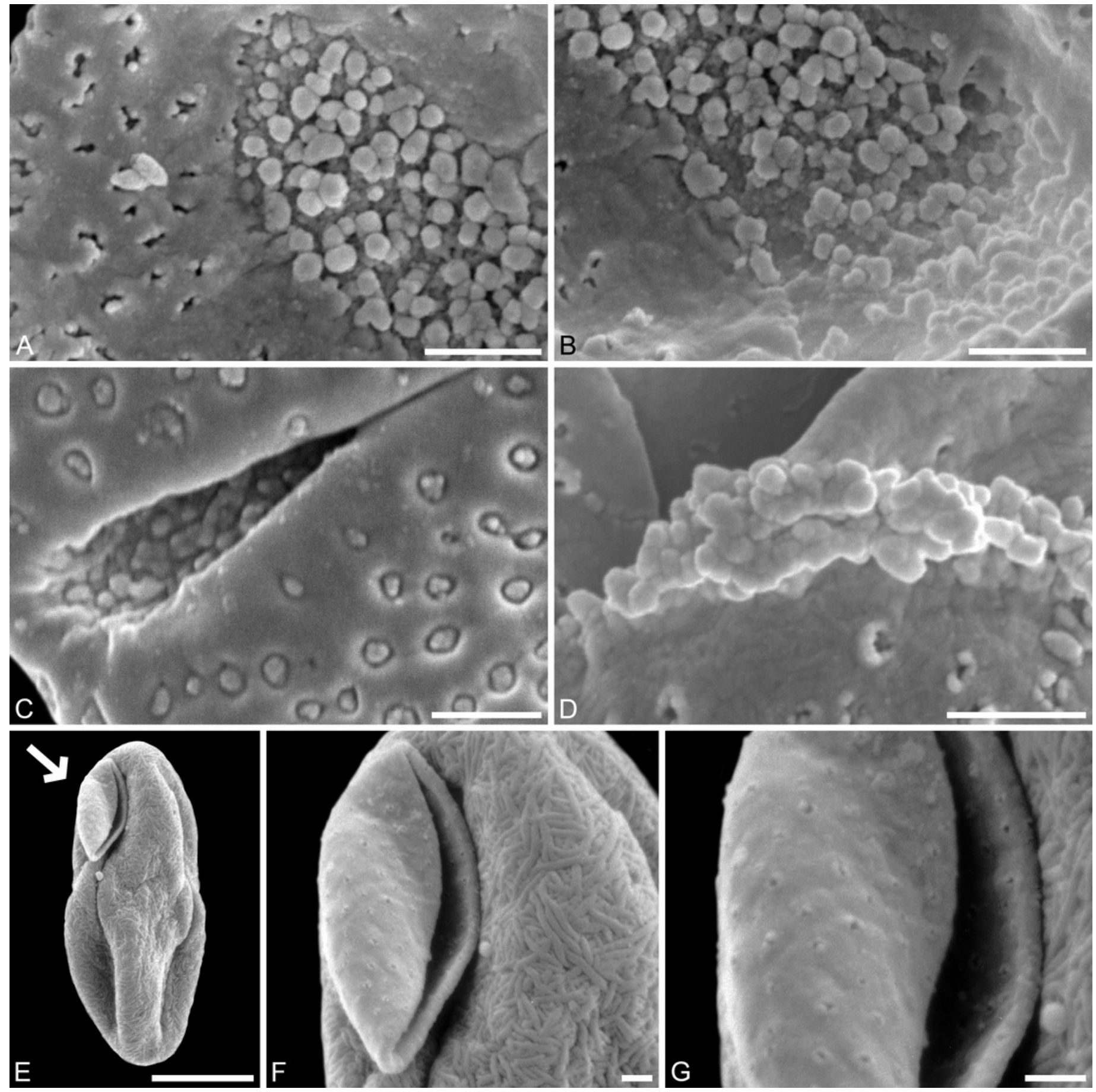


\section{Figure 8}

Mapping of the fossil record (circles, stars) of Saururaceae on dated phylogenies (Bayesian uncorrelated clock; included in Massoni, Couvreur \& Sauquet 2015a)

Oldest fossils of the Winteraceae are shown for comparison. Pink: North American fossils; cyan: western Eurasian (Central Europe to western Siberia) fossils; yellow: East Asian fossils; stars: fossil pollen described here. Blue bars represent the $95 \%$ highest posterior density (HPD) intervals of the minimum age and maximum age scenarios; node heights are averages (medians are indicated by deep blue bars in the HPD intervals). Branch labels show posterior probabilities $(\mathrm{PP})<1.0$ (all other branches have $\mathrm{PP}=1.00$ ), red branches highlight topological conflict between the chronograms (probably due to incomprehensive Bayesian runs getting stuck in local suboptima, since all analyses were based on the same data set). 


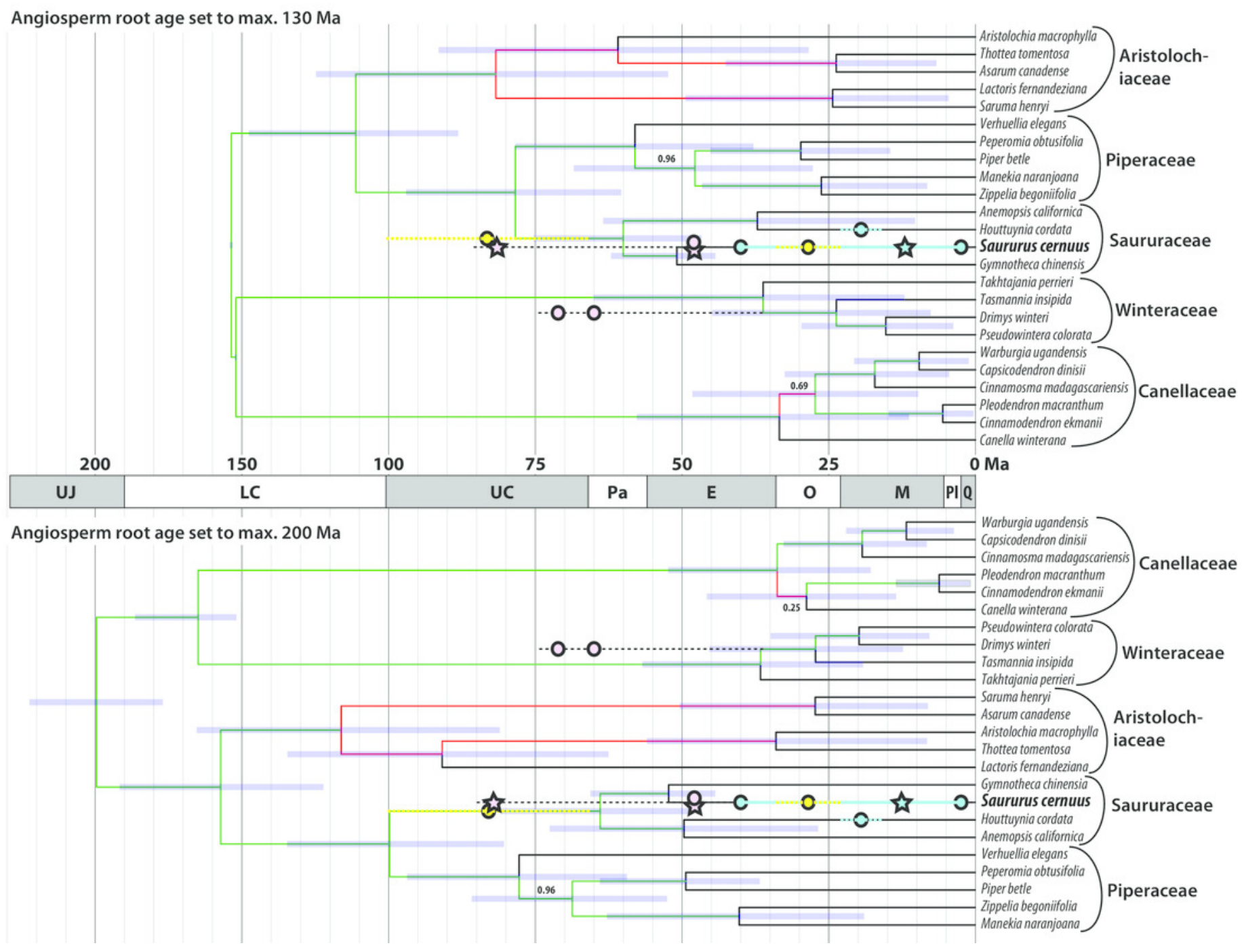




\section{Figure 9}

Hypothetical evolution of Saururaceae pollen

The fossil and extant Saururus show a morphology that may be primitive within the family: all other genera differ by one or two unique, putatively derived traits. Abbreviations: PS = (normal) pollen surface; $\mathrm{SM}=$ sulcus membrane. Scale bars $=1 \mu \mathrm{m}$.

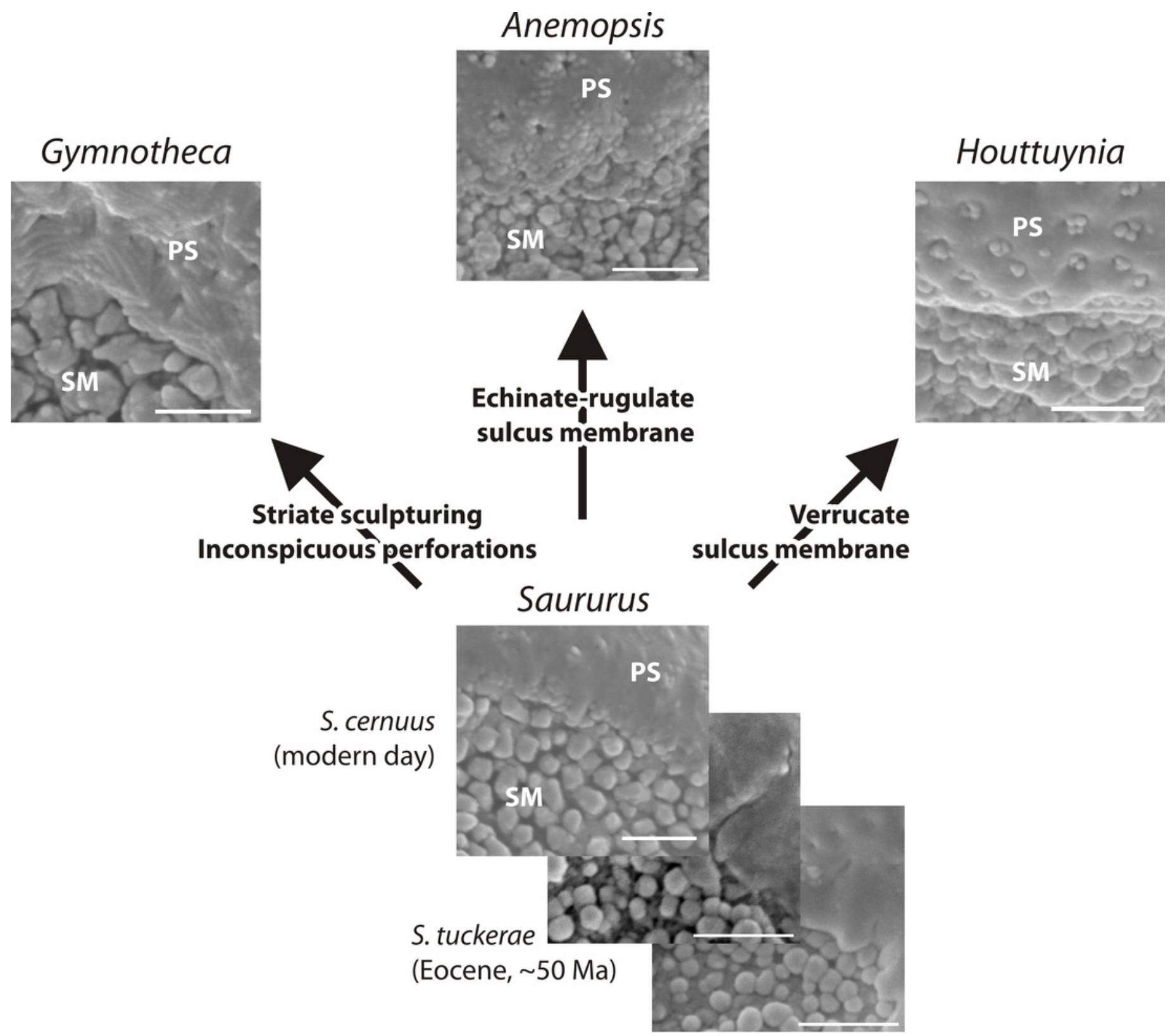

S. aquilae

(Campanian, $80 \mathrm{Ma}$ ) 